\title{
The impact of interest-rate subsidies on long-term household debt: Evidence from a large program*
}

\author{
Nuno C. Martins ${ }^{\dagger} \quad$ Ernesto Villanueva ${ }^{\ddagger}$
}

October 2003

\begin{abstract}
The responsiveness of long-term household debt to the interest rate is a crucial parameter for assessing the effectiveness of public policies aimed at promoting specific types of saving. This paper estimates the effect of a reform of Credito Bonificado, a large program in Portugal that subsidized mortgage interest rates, on long-term household debt. The reform established a ceiling in the price of the house that could be financed through the program, and provides plausibly exogenous variation in incentives. Using a unique dataset of matched household survey data and administrative records of debt, we document a large decrease in the probability of signing a new loan after the removal of the subsidy.
\end{abstract}

Keywords: Consumer Borrowing, Subsidies, Quasi-natural experiment.

JEL Codes: D91, E21, H20.

\footnotetext{
${ }^{*}$ We would like to thank participants at seminars in the 2003 North American Summer Meetings of the Econometric Society, the second TMR network on the "Economics of Aging," Universitat Pompeu Fabra, Universidade Nova de Lisboa, Università Roma II (Tor Vergata) and Banco de Portugal. We owe special thanks to Antonio Ciccone, Esther Duflo, Ed Glaeser, Sergi Jiménez, Adriana Kugler, Max Pinheiro, James P. Smith and Guglielmo Weber for their comments and suggestions. Pedro Próspero provided outstanding computing support. Villanueva's research was funded by the Spanish Ministry of Science and Industry through grant SEC2001-0674. The analysis, opinions and findings of this paper represent the views of the authors, they are not necessarily those of the Banco de Portugal.

${ }^{\dagger}$ Banco de Portugal and Universidade Nova de Lisboa, Av. Almirante Reis, 71, 1150-012 Lisbon, Portugal. E-mail: nmartins@bportugal.pt

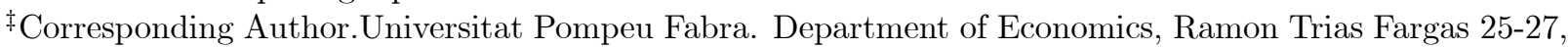
08005 Barcelona, SPAIN. Email: ernesto.villanueva@upf.edu
} 


\section{Introduction}

The impact of changes in the interest rate on long-term household borrowing is an important parameter for assessing the effectiveness of at least two important public policies. First, the response of household borrowing to changes in interest rates helps us to understand the determinants of investing in housing wealth and, ultimately, the effectiveness of public policies that affect interest rates. ${ }^{1}$ Second, home mortgage interest rate subsidies are a common feature of the tax codes of OECD countries -Poterba (2001). ${ }^{2}$ The response of household borrowing to financial incentives is a likely channel through which mortgage interest rate deductions alter the composition and lifetime profile of individual's savings. ${ }^{3}$ This paper estimates the impact of the interest rate on household debt by exploiting a reform in a large program that subsidized mortgage interest rate payments of two groups commonly considered to be on the home ownership margin: young and lower income individuals.

Previous researchers have identified the effect of interest rate incentives on long-term household debt by examining "quasi-experimental" variation induced by tax reforms. Maki (2001) and Scholz (1994) study the effects of changes in the tax treatment of borrowing on household debt composition. They document that the US Tax Reform Act of 1986, that eliminated the tax deduction on interest payments associated with consumer debt, increased the demand for mortgage debt. Nevertheless, these studies do not estimate the overall interest elasticity of consumer borrowing. Jappelli and Pistaferri (2002) provide evidence about the responsiveness of household mortgage debt to tax incentives using a reform in the Italian tax system in 1993. They find that the change in tax incentives for taxpayers did not affect the relative probability of acquiring mortgage loans, and argue that lack of financial information makes households

\footnotetext{
${ }^{1}$ Attanasio, Goldberg and Kyriazidou (2000) show in a durable goods context that liquidity constraints dampen the response of household borrowing to changes in interest rates.

${ }^{2}$ Poterba (2001) reviews the tax incentives to mortgage borrowing in several OECD countries. While the United States, Netherlands, France and Italy provide tax incentives to mortgage debt, only the tax code in Netherland provides tax incentives to consumer debt. Glaeser and Shapiro (2002) claim that, in the US, after state taxes, home mortgage interest deduction is the the most common deduction.

${ }^{3}$ Poterba (1984) derives the user-cost of housing as a function of the mortgage interest rate deduction. Gervais (2002) shows that the interaction between non taxing imputed rents and mortgage interest rate subsidies introduces a wedge between the after-tax return on saving in housing and the return on saving in other financial assets. He uses a dynamic general equilibrium model to illustrate that removing mortgage interest rate deductions decreases the home-ownership rate and household debt, and increases consumption early in life.
} 
unaware of the tax advantages associated with acquiring mortgage debt. ${ }^{4}$

This paper identifies the effect of mortgage interest rate subsidies on total long-term household borrowing by exploiting a reform of a large program in Portugal called Credito Bonificado (CB program). The CB program was launched in 1986 as a system of subsidies to individuals with lower incomes who wanted to purchase a house financed by a mortgage loan. In the last quarter of 1998 a national-level ceiling was established on the value of the house that could be bought through the program, so that eligible households willing to buy a house whose price exceeded the ceiling did not qualify for any subsidy at all. Simple calculations show that the present value of the stream of mortgage payments due by an eligible individual could increase up to $26 \%$ with respect to the pre-reform period. Our identification strategy relies on the following idea. A uniform ceiling is most likely to bind in regions in which the average price of real estate was highest before the reform. Hence, we compare the trend in the borrowing behavior among individuals eligible for the subsidy who lived in regions with high real estate prices to the borrowing behavior of ineligible individuals and of eligible individuals living in regions where the price of real estate was low pre-reform.

There are four main reasons that make the analysis in the present work an interesting setup to analyze the impact of the interest rate on household borrowing. The first reason is that, unlike the CB program, most tax codes have one of the following two characteristics that hinder their effectiveness. Home mortgage interest rate subsidies reimburse the subsidy only after the payment has been made, and they usually provide higher implicit subsidies to individuals with high taxable income. ${ }^{5}$ Hence, tax incentives benefit individuals who are likely to access debt markets even in the absence of the subsidy (see Glaeser and Shapiro, 2002). In contrast to these features, the CB program targeted young individuals and individuals in the lower

\footnotetext{
${ }^{4}$ This paper focuses on the response of the probability of acquiring long-term household debt to changes in the interest rate (the extensive margin). Gary-Bobo and Larribeau (2003) estimate the response of household mortgage debt amount to the interest rate among household who choose to acquire debt (the intensive margin). There is a related literature on the response of consumer debt to changes in the interest rate (Gross and Souleles, 2002, and Alessie, Hochguertel and Weber, 2001). There is also a substantial literature on the effects of tax incentives on household saving. Engelhardt (1996) exploits the cancellation of a program in Canada that provided tax subsidies to savings towards the purchase of a house, and finds that changes in tax incentives increase national saving. The US evidence on the effects of tax incentives on household saving is more controversial. See Bernheim (2002) for a survey.

${ }^{5}$ The Mortgage Interest Relief at Source (MIRS) is an exception to the rule of reimbursement after the payment is made. See Devereux and Lanot (2003) for a detailed description of the MIRS program in the UK.
} 
part of the income distribution, and it provided subsidies at the source, that is, the individual did not have to pay the installment before getting the subsidy. The second reason is that the CB program provided four different subsidies to eligible individuals, a feature that allows us to examine the responses of several treatment groups to the change in incentives. Third, while tax incentives may not be effective because individuals lack the relevant information about financial markets, or about the tax code (see Jappelli and Pistaferri, 2002, 2003), the CB program was well-known in Portugal. In 1998, two out of three new mortgages signed were subsidized by the CB program. Fourth, we use a unique sample obtained by merging household survey data to administrative records on individual debt. Most of the work on the impact of tax incentives on individual debt is based on household surveys, which usually measure wealth and debt at the aggregate household level. Our sample enables us to study the borrowing behavior of different individuals within the household: an important advantage when studying borrowing patterns in a country with thin rental markets and extended co-residence between young adults and their parents.

Our estimates suggest that the loss of access to the subsidy coincided with a fall in the probability of signing a new loan by between 4 and 10 percentage points, depending on the eligible group considered. These estimates imply a large elasticity of the probability of borrowing to changes in the mortgage interest rate subsidies of -2.9 . The estimates are robust to alternative functional form specifications, and contrast to recent findings on the effect of tax incentives household on mortgage borrowing behavior. We also document that the response of borrowing to the changes in the interest rate is especially high among young adults who coreside with their parents. An interpretation of this result is that young adults react to adverse housing market conditions by staying with their parents, a pattern of behavior documented in other Southern European countries (see e.g. Martínez-Granado and Ruiz-Castillo, 2002 or Manacorda and Moretti, 2001).

The paper is organized as follows. In Section 2, we describe the characteristics of the CB program, and the details of the 1998 reform. Section 3 uses a simple analytical framework, adapted from Henderson and Ioannides (1983) to claim that the reform under consideration can be used to estimate the response of the probability of getting a new loan to changes in the interest rate. Section 4 describes the data and discusses our empirical methodology. Section 5 
provides the baseline empirical results, and assesses potential explanations for the discrepancy with previous findings in the literature. In Section 6, we test our empirical methodology, by examining whether pre-existing trends could explain our results, and by discussing the extent to which the CB scheme was passed on to real estate prices. Section 7 concludes.

\section{The Credito Bonificado Program}

In 1986, the Portuguese Government enacted the Credito Bonificado (CB program), a program intended to stimulate the access to home ownership among young and low-income individuals. The CB program provided various types of interest rate reductions at source to eligible households who financed with a mortgage loan either (a) the purchase of the house of residence or (b) the construction or repairs of the house of residence or (c) the purchase of land towards the construction of the house of residence. Only households with taxable income below a given threshold, and who were not currently holding any type of mortgage debt were eligible for the program. The amount of the loan could not exceed the total value of the house, and a person purchasing a house financed with a subsidized loan was not allowed to sell it within a period of five years. ${ }^{6}$

The CB program subsidized a proportion of the monthly interest rate payments of a mortgage loan. The subsidy was given by the Portuguese Ministry of Finance directly to the lending institution, so that any household receiving the subsidy had its monthly payment effectively reduced from the first installment on. The subsidized proportion was constant for the first two years of the loan, fell at a $1 \%$ rate during the subsequent three years of the life of the mortgage loan, and at a $2 \%$ rate thereafter, until exhaustion. ${ }^{7}$ The proportion subsidized

\footnotetext{
${ }^{6}$ If the house was sold before the time limit, the individual would be obliged to return the amount subsidized plus a premium. Under some circumstances, such as moving to another region for work-related circumstances, the government could waive the obligation to return the subsidy. Decree-law n. 328-B/86, September 30th, 1986.

${ }^{7}$ In addition to the standard CB program, the government provided an extended subsidy to young individuals, called Credito Bonificado Jovem (CB-young, hereinafter). This extended subsidy targeted singles less than thirty years old or couples with the sum of ages less than fifty-five. For the CB-young program, the subsidy was constant for the first four years, decreased at a $1 \%$ rate during the following two years and after that at a $2 \%$ rate until exhaustion. We ignore this differential subsidy throughout the analysis, as simulations using the example in Table 1 (not shown) suggest that the differential subsidy for the young was $2 \%$ of the corresponding subsidy for the regular program. We also ignore the mortgage interest rate subsidy in the Portuguese tax code, which is relatively small.
} 
depended negatively on the taxable income of the family, following an adjustment for family size. $^{8}$

The program offered a $44 \%$ subsidy on interest rate payments during the first two years of the loan to households whose (adjusted) taxable income was below 3.25 times the minimum annual income (class 1.) The corresponding starting subsidy was $32.5 \%$ for households with taxable income between 3.25 and 3.50 times the minimum annual income (class 2.) Households with taxable income between 3.5 and 4.25 times the minimum annual income (class 3 ) had an initial subsidy of $21 \%$ of interest rate payments, and those with taxable income between 4.25 and 4.75 the minimum annual income (class 4), the initial subsidy was $10 \%$ of the interest rate payment. According to our sample (see Section 4), 67\% of Portuguese taxable units, between 18 and 55 years of age, qualified for the maximum subsidy, $7 \%$ for the class 2 subsidy, $5 \%$ for the class 3 subsidy and $3 \%$ for the class 4 subsidy.

Table 2 illustrates an example of the savings associated with the CB program. We assume an initial mortgage loan of 48,000 euro with twenty-five-year maturity, a constant interest rate of $8 \%$. The first column shows the evolution of the amount of outstanding debt. The second column shows the (constant) stream of payments. The fourth column presents the stream of payment in period-zero euros which, by construction, must add up to the initial loan amount of 48,000 euro. The fifth column presents the annual percentage of subsidy for a family in class 1 subsidy and the sixth column the actual yearly payment. Discounting the stream of payments to the moment in which the mortgage was granted and summing up the amounts yields 36,408 which represents $76 \%$ of the amount paid by a family with an identical mortgage, but without the subsidy. Similar analyses for the other classes of subsidy show that individuals in classes 2, 3 and 4 would pay respectively, $84 \%, 92 \%$ and $97 \%$ of the baseline 48,000 euro. Aggregate evidence suggests that the subsidy was effective, in the sense that it was not passed-through into higher interest rates. ${ }^{9}$

\footnotetext{
${ }^{8}$ The adjustment consisted in deducting an amount from the taxable income of the family. The deduction depended on family size. Details on the data appendix.

We use "household" as the eligible unit for the program. As explained in Section 4, the taxpaying unit in Portugal is the family. Couples are required to file taxes jointly, and individuals above 18 years of age living with his or her parents, have the option of either filing taxes with his or her parents, at the head's marginal tax rate or filing individually, if personal income exceeds a threshold.

${ }^{9}$ Aggregate records of average interest rates by loan type, provided by the Portuguese Ministry of Finance, show that in February 2001, the average interest rate charged to a person with a CB loan was 7.59 per cent,
} 
The subsidy provided by the CB program could potentially have a significant impact on household net income. Using the 2000 wave of the Inquerito ao Patrimonio e Endividamento das Familias (IPEF), we have estimated that monthly mortgage payments represented, on average, $21 \%$ of total net household income. ${ }^{10}$ This means that the subsidy on mortgage loans could represent up to $9.3 \%$ of monthly net income at the period of maximum subsidy for class 1 households.

In the last quarter of 1998, the Portuguese Government reformed the program. To be eligible for the subsidy, households satisfying the income requirements could not purchase a house above a ceiling. The particular limit depended on the taxable income and on the family size of eligible households, but not on the place of residence. ${ }^{11}$ For example, a twoperson household with income below 3.25 times the minimum annual income could only be subsidized for the purchase of a house whose price was below 63,500 euro (in euros of 1998.) If the value of the purchased house exceeded the value of the ceiling by one euro, the household was no longer eligible for any type of subsidy (aside from the standard income tax deduction, which is very small in Portugal.) The reform was effective in the second quarter of 1999, and hereinafter, we refer to it as the 1999 reform.

We have used the IPEF 2000 to compute the average values of the houses for the various eligible classes and compare them to the 1999 ceilings. According to our own calculations from the IPEF 2000, the average (median) value of a house bought before 1999 by households eligible for the maximum subsidy was 71,028 euro (62,350 euro). We have estimated that the limits introduced by the reform were in the 60th percentile of the distribution of the value of houses bought by eligibles before the 1999 reform.

Figure 1 shows the evolution of the number and the value of mortgages created during

while the average interest rate charged to a non-CB loan was 7.43. From February 2001 until May 2002, the difference in the charged interest rates never exceeded 16 basis points. See Devereux and Lanot (2003) for evidence on the incidence of MIRS on mortgage financial costs.

${ }^{10}$ The IPEF is a survey on wealth holdings of Portuguese households, conducted for the first time in the year 2000.

${ }^{11}$ The limit was established according to the decree-law n. 349/98, November 11th, 1998. For eligibles of class 1 , the limit was 62,350 euro, 68,585 euro, 81,055 euro or 87,290 euro if the family size was $1,2,3$ or 4 , and above, respectively. Conditional on family size, households eligible for the class 2 subsidy had higher limits: 69,832 euro (1 individual), 76,815 euro (2 individuals), 90,781 euro (three or four individuals) and 97,764 euro (five or more). The corresponding limits for class 3, were: 77,314 euro, 85,045 euro, 100,508 euro and 108,239 euro, and finally, for class 4 the limits were: 84,796 euro, 93,275 euro, 110,234 euro and 118,714 euro. 
the period spanning 1990 and 2001. ${ }^{12}$ Probably due to the steady decrease in the interest rates over the decade and to the increase in competition in the commercial banking sector, mortgage loans significantly increased after 1994. ${ }^{13}$ Between 1994 and 1998, the aggregate value of mortgage loans increased from 3 billion euro until 12 billion euro. In 1994, one out of two new euros of mortgage debt were borrowed under CB loans. In 1998, the proportion rose to two out of three euros borrowed through CB loans. After 1999 the total amount of mortgage debt and the relative proportion of euros created through the CB loans decreased dramatically. In 2000 only 43 cents out of each euro of new mortgages were borrowed through the program. ${ }^{14}$

The evolution of total number of mortgages is similar to the evolution of the total value of loans. In 1994, 84,445 mortgages were issued, with an average value of 35,702 euro. Among these, CB loans accounted to 43,875 contracts with average value of 34,141 euro per loan. By 1998, the total number of new mortgages was 216,631 (average value of 48,351 euro per mortgage). In that year the CB program contributed with 130,335 loans, with an average value of 51,239 euro per loan. By the end of 2001, the number of total new loans decreased to 153,134 (average loan of 64,425 euro) where the CB loans were 67,351 with an average value of 63,115 euro per loan. The pattern described above suggests that the 1999 reform had a substantial effect on the borrowing behavior of households. We use this reform to estimate the effect of a change in the interest rate on household long-term debt, using micro data from the period spanning 1998 and 2001.

\section{Framework for the analysis}

This section uses a simple model of consumption of housing services (see Henderson and Ioannides, 1983) to discuss how the 1999 reform in the CB program can be used to identify

\footnotetext{
${ }^{12}$ Source: Portuguese Ministry of Finance (http://www.dgt.pt/informacoes/default.htm).

${ }^{13}$ Between the end of 1994 and the end of 2001, the country aggregate interest rate implicit on outstanding household loans with maturity of 5-years or longer decreased from an average of $13 \%$ to $5 \%$. During this period, the 6 -month interest rate benchmark (Lisbor) decreased from $11.3 \%$ to $2.64 \%$ by May 1999 . It increased to $3.57 \%$ by the end of 2001 .

${ }^{14}$ According to our calculations from IPEF 2000, the take-up rate of the CB program among eligible households was $51 \%$. However, this number could be biased, as eligibility class is measured in year 2000, when the household is interviewed, but not at the moment of signing the loan. This take-up rate would be comparable to the take-up rate of $401(\mathrm{k})$ in the US during the mid-eighties (see Engen and Gale, 2000.)
} 
the effect of an exogenous change in the interest rate on consumers' borrowing behavior. We claim that the reform allows us to get a lower bound on the effect of the interest rate on borrowing behavior.

Let a consumer who lives for two periods and cares about non-durable consumption today $\left(c_{1}\right)$, tomorrow $\left(c_{2}\right)$, and about the amount of housing services $(h)$, with utility function $U\left(c_{1}, c_{2}, h\right)$. We also assume perfect certainty, and that the consumer receives income $y_{1}$ in the first period, and $y_{2}$ in the second. In the first period, the consumer chooses whether or not to acquire housing services $h$ at a cost of $p$ euro per unit. The consumer has an outside option yielding a utility level $\bar{U}$ that involves consuming an amount of services $\bar{h}$. Investment in housing neither depreciates nor increases its value. The consumer can access the credit market, at an interest rate $r$, but only to acquire housing services, and with the constraint that the amount borrowed per unit of housing services $m$ cannot exceed the total price of housing services, $p$. The intertemporal budget constraint of the consumer is the following (see Appendix B for details)

$$
c_{1}+\frac{c_{2}}{1+r}+\frac{r}{1+r} p h=y_{1}+\frac{y_{2}}{1+r}
$$

We concentrate on the case in which income in the second period $y_{2}$ is sufficiently high relative to the first period $y_{1}$, so that the consumer must finance at least a part of the purchase of services through a mortgage. In that setting, acquiring new housing services requires borrowing in the debt market. ${ }^{15}$

Let the equation (BC) represent the budget constraint for an eligible individual in the pre-1999 reform situation. This individual faces an effective after-subsidy interest rate of $r(1-.24)$, where $r$ is the market interest rate, and we make use of the computations in Table 1. The budget constraint is represented in Figure 2. The full (dotted) line represents the pre(post-) 1999 reform budget constraint (ignoring wealth effects caused by the change in the interest rate.) Before the 1999 reform, the consumer could trade-off any amount of housing services $h$ and life-cycle non-durable consumption at a relative price of $p \frac{r(1-.24)}{1+r(1-.24)}$, or $p \frac{.76 r}{1+.76 r}$.

\footnotetext{
${ }^{15}$ Also, we only examine the net borrowing of the consumer, and hence ignore the decision to save. An alternative justification to ignore the saving decisions is that consumers faced a higher interest rate for borrowing $r_{b}$ than for lending $r_{l}$. It is easy to prove that, in this situation, the consumer either borrows or saves, but not both -see Attanasio et al. (2000).
} 
The 1999 reform introduced a severe discontinuity, as eligible individuals did not qualify for any subsidy at all if the value of housing services purchased exceeded the ceiling $L$ by one euro. At the value of the ceiling, the relative price of housing services became $\frac{r}{1+r}$.

Our parameter of interest is the response of consumers' borrowing behavior to a change in the interest rate from the first euro borrowed, holding $p$ constant. Hence, we discuss three possible responses to the 1999 reform, according to the preferences of individuals, and how these responses relate to the parameter of interest.

Case 1 Individuals with low preference for housing services are not affected by the reform.

That is the case of individuals who, at the pre-reform cost of housing services, demand an amount of $h$ such that $p h$ is below the ceiling $L$. Nevertheless, if these individuals had experienced an increase in the housing cost from the first unit of housing services, they would have diminished their propensity to borrow. Hence, the introduction of a ceiling does not affect the borrowing behavior of these individuals.

Case 2 For individuals with intermediate preferences for housing services, the change in the probability to borrow after the introduction of a ceiling underestimates the uncompensated derivative of the probability to borrow with respect to a change in interest rate from the first euro borrowed.

The preferences of these individuals are such that their demand for housing services at the pre-reform cost of housing exceeds the ceiling, and their outside option, (which does not involve the acquisition of a mortgage loan) yields lower utility than consuming at the ceiling. Hence, these consumers respond to the reform by purchasing housing services at the value of the ceiling, while if the cost of borrowing had increased from the first euro, they would have chosen the outside option. The situation is illustrated in figure 2 . The indifference curve representing the utility of not participating in the housing market $(\bar{U})$ cuts the pre-reform budget constraint of the consumer to the left of the ceiling. At the pre-reform cost, the consumer is better off consuming housing services than with the outside option. Nevertheless, if the 1999 reform had not introduced a ceiling, the consumer would have left the housing 
market, as her $\bar{U}$ lies to the northeast of an alternative budget constraint with slope $\frac{r}{1+r}$ from the first unit of housing services.

Also, note that among consumers who purchase housing services both at the pre- and post1999 interest rates, the introduction of a ceiling may make it optimal to reduce the amount of housing services to the ceiling, so that the new demand for housing services is much lower than the optimal choice at the post- 1999 reform interest rate in the absence of a ceiling. Then, for a given price of housing services, the introduction of a ceiling can cause the observed change in the amount borrowed before and after the 1999 reform to be either an underestimate or an overestimate of the uncompensated derivative of the amount borrowed to a change in the interest rate.

Case 3 For individuals with high levels of preference for housing services, the change in the probability to borrow after the introduction of a ceiling does provide an estimate of the uncompensated derivative of the probability to borrow to a change in interest rate.

Consumers in this group are characterized by their desired amount of housing services being above the ceiling both at the pre- and post- reform cost of housing. Also, they derive higher utility consuming housing services above $\frac{L}{p}$ at the post- reform interest rate than at the ceiling. These consumers choose to get additional housing services depending on whether or not the utility of the outside option is higher or lower than the utility acquiring services at the post-reform cost of housing. The change in the propensity to borrow for this set of consumers after the reform is the same as if the post-reform cost of housing was $\frac{r}{1+r}$ from the first euro.

Summarizing all cases, we obtain the following claim, proven in Appendix B.

Claim 1 Holding $p$ constant, the change in pre-and post- reform participation in the mortgage market after the introduction of a ceiling provides an underestimate of the response of the propensity to borrow to the change in the cost of a mortgage from the first euro borrowed. This is not necessarily the case for the evolution of the amount of debt.

Claim 1 assumes that $p$, the unit price of housing services is constant. Yet, there is substantial regional variation in the price per unit of housing, which has consequences for 
the effectiveness of the reform. Assume that the elasticity of the expenditure in housing services with respect to the price $p$ is positive (equivalently, that the elasticity of housing services with respect to the price is negative but smaller than one in absolute value.) Holding the distribution of preferences constant across regions, individuals living in regions with high prices are more likely to spend higher amounts in housing services than similar individuals living in low-price regions. ${ }^{16}$ The ceiling $L$ was set at the national level and, consequently, case 1 is more likely to occur in areas with low average prices than in areas with high average prices. The change in borrowing behavior after the reform is likely to be stronger in regions with higher pre-reform real state prices. That heterogeneity in responses to the reform provides the basis for our empirical test.

In Section 4.2, we group consumers who live in areas that were "expensive" or "inexpensive" prior to the 1999 reform, and estimate the effect of the change in the interest rate on the probability of borrowing from the differential response of the propensity to borrow between eligibles in "high-price" areas and eligibles in "low-price" areas. Our identifying assumption is that the reform in the CB program did not affect the propensity to borrow among eligibles living in low-price areas. That assumption is supported by the evidence in Section 5, documenting that within "low-price" areas, eligible individuals did not significantly decrease the probability of signing new loans with respect to non-eligibles. ${ }^{17}$

Given that the evolution of the amount of debt after the reform can be a biased estimate of the derivative of the debt amount to the change in the interest rate, and that the sign of the bias cannot be determined a priori, we focus the discussion on the analysis of the extensive margin: i.e., on the probability of signing a new loan. Finally, we focus the discussion in the demand side of the housing market and, in Section 6.2, we discuss to what extent the 1999 reform affected the evolution of housing prices.

\footnotetext{
${ }^{16}$ In Appendix B, in claim 2, we discuss the conditions under which the elasticity of the expenditure in housing services increases with the price $p$.

${ }^{17}$ In the empirical analysis we identify "high -price" areas as counties in which the average price of a purchased house in 1998 exceeded the national average.

The evidence in Table 4 supports the hypothesis that the effects of the 1999 reform on the propensity to borrow were not negative in low-price areas.
} 


\section{The Data}

Our sample combines a representative Portuguese household survey including employment status, demographics and income and administrative records of outstanding debt levels. The main source of data is drawn from a quarterly rotating panel called Inquérito ao Emprego (IE), from 1998 to 2001. The IE follows respondents for at most six consecutive quarters, and includes information on the educational level of the individual, labor force status, occupation, industry and demographics, much like the US CPS. Unfortunately, it does not contain any asset information.

The debt data are taken from the Central de Risco de Crédito database (CRC) collected by the Banco de Portugal (Portuguese Central Bank). This dataset is unique in the sense that it is a panel of all Portuguese individuals who hold any debt from financial institutions between 1995 and 2001. Each Portuguese financial institution authorized to lend credit to consumers, is required by law to report to the central authority the amount of individual debt and, in the case of short-term debt, credit limits. ${ }^{18}$ The information on the CRC sample includes separate records for the stock of debt held by a given individual with maturity of less than a year and for the stock of debt with maturity exceeding one year. Hence, for each individual, we do not know whether or not a specific loan is a mortgage or a consumer loan. The IE and the CRC records were matched by the staff at the Banco de Portugal using variables common across the two databases, namely the exact date of birth, the gender of the individual, and the place of residence (county) the individual lived in, one year before the interview.

Given that claimants for the CB program had to present their last tax return to be eligible for the program, the unit of observation in our analysis is the combination "taxpaying unit"year. The taxpaying unit coincides with the household in the case of married individuals, as in Portugal married couples must file jointly. Hence, each married couple or each single individual living in their own household and earning income above the minimum yearly wage contributes one observation per year. The case of individuals above the age of 18 , who earn income and

\footnotetext{
${ }^{18}$ The Bank of Portugal centralizes all outstanding individual debt. The CRC database is confidential, but can be used by financial institutions upon certain circumstances. If an individual asks a bank for a loan, the commercial bank is allowed to obtain a report from the Central Bank with the current total outstanding debt of this individual.
} 
co-reside with their parents, is slightly more complicated. According to the Portuguese law, these individuals may opt for filing jointly with their parents or for filing taxes separately. There are clear incentives in most cases to file separately from parents, both to pay less tax and to qualify for the CB program. Also, the group of co-residing young adults is likely to benefit the most from the CB program, as the transition to home ownership in Portugal does not occur through the rental market, but young adults reside with their parents well into their twenties and then purchase the home of residence. ${ }^{19}$ Based on these considerations, we consider as a separate tax-paying unit each dependent individual above 18 residing with his or her parents and earning income.

Also, we construct our sample in the following way. The time unit of the IE is the quarter, so the combined sample consists of 13 quarterly surveys. Nevertheless, we are interested in the probability of signing a loan in a given year. ${ }^{20}$ Hence, we pooled together observations from all the quarterly surveys and kept one observation per individual per year.

We restrict the initial sample to "taxpaying units" in which the main earner is between 18 and 55 years of age, is not self-employed and whose reported income exceeds the minimum yearly wage. As CB claimants could not have any outstanding mortgage, we also drop individuals who already had debt at the beginning of the survey year. To determine eligibility, we add the earnings of both spouses in the case of married individuals. ${ }^{21}$ When computing family size, we exclude individuals in the household who are 18 years or more and report positive income. Each individual contributes at most one observation per year, and we use information from three years: 1998, 2000 and 2001 (1999 is excluded, given that it was a transitional

\footnotetext{
${ }^{19}$ Data from the 1998 Inquerito ao Emprego (first quarter) indicate that $75 \%$ of young adults between 18 and 30 years of age reside with their parents.

${ }^{20}$ In earlier drafts of the paper, we estimated the probability of signing a loan in a given quarter, keeping all the observations from all quarters in the IE. The results were very imprecise, probably because the probability of signing a new loan in a given quarter is a very low-probability event (it was around 1 per cent among eligibles for the maximum subsidy.)

${ }^{21}$ The details of the eligibility measure are described in Appendix A. Eligibility for the CB subsidy depends on family income and family size. The Inquerito ao Emprego contains information on monthly net labor income for salaried workers, business income for self-employed, unemployment benefits for unemployed, and pension income for retirees. We use only salaried workers, unemployed or retired individuals, and impute pre-tax labor income from the standard withholding rules in the Portuguese law. We do not have direct information on transfer income or asset income. Hence, the eligibility measure could be subject to measurement error. We have computed the proportion of household income that comes from labor earnings using the 2000 IPEF survey, and this amounts to $93.4 \%$ of total earnings. The proportion of eligibles in both samples is similar.
} 
year.) Note that the rotation scheme may make individuals contribute two observations to the sample.

The dependent variable takes a value of zero if the individual held zero debt during the four quarters of the survey year, and 1 if the amount of outstanding debt changed from zero to more than 5,000 euro during any of the four quarters of the survey year. ${ }^{22}$

As discussed in Section 3, an important variable in our analysis is whether an individual lives in a "high-price" county prior to the passage of the 1998 reform. The Portuguese National Statistics Agency only started collecting average prices of houses sold in 2001. These prices may be the consequence of the passing of the reform. To get the distribution of pre-reform prices by county, we deflated prices of houses using an index for prices collected by the Banco de Portugal during the period 1998-2001. ${ }^{23}$ We further restrict the sample to counties in which real estate prices in 1998 are available. ${ }^{24}$

Overall, we have 16,587 observations from 13,819 individuals. ${ }^{25}$ Table 2 presents the summary statistics of our sample. $83 \%$ of the individuals in our sample are eligible for the program and $68 \%$ qualify for the maximum subsidy. Table 2 suggests that the probability of having a new loan increases with the income classes, from $6 \%$ among the households that are eligible for class 1 to $12 \%$ for the individuals that are not eligible. The amount of new loans is on average 29,977 euro.

\subsection{The empirical methodology}

We begin by estimating variants of the following model.

$$
\begin{aligned}
1\left(D_{i t}>\right. & 0)=\alpha_{0}+\alpha_{1} E L_{-} 1_{i} * A F T E R_{t}+\alpha_{2} E L_{-} 2_{i} * A F T E R_{t} \\
& +\alpha_{3} E L_{-} 3_{i} * A F T E R_{t}+\alpha_{4} A F T E R_{t}+\sum_{j=1}^{j} \alpha_{4+j} E L_{-} J_{i}+\alpha^{\prime} X_{i t}+\theta_{i}+\eta_{i t}
\end{aligned}
$$

\footnotetext{
${ }^{22}$ Casual discussions with various mortage branch managers in Lisbon, from different financial groups, suggest that EUR 5,000 is a lower bound for a mortgage. In Table 5, we experiment with a limit of 7,500 euro.

${ }^{23}$ The real estate indices are based on monthly data from real estate agencies, i.e., prices of the supply of housing services. These data are gathered by the company Confidencial Imobiliário.

${ }^{24}$ There are 278 counties in Portugal, and their average area is $306 \mathrm{~km}^{2}$. For our analysis, we use observations on 117 counties, for which the evolution of housing prices is available.

${ }^{25} 11,051$ individuals contribute one observation, and 2,768 individuals contribute two observations. The number of observations in 1998, 2000 and 2001 is $7,247,5,903$, and 3,437, respectively.
} 
First, we discuss the case in which the dependent variable takes value one if the household acquired during the present year (any type of) debt with maturity longer than one year, and zero otherwise. $E L_{-} 1_{i}, E L_{-} 2_{i}$, and $E L_{-} 3_{i}$ are binary variables indicating whether or not the individual is eligible for the program, and what eligibility class the individual belongs to. ${ }^{26}$ The omitted group includes individuals who are not eligible for the program. AFTERt is a binary variable that takes value 1 if the new loan is signed in the post-reform periods of 2000 and 2001 and 0 if it is signed in the 1998 period. $X_{i t}$ contains demographics affecting the individual's propensity to borrow, such as a polynomial in age, family status variables and whether the individual co-resides with parents (listed in Table 4.) Finally, we allow for an individual-specific error term, $\theta_{i}$, that we assume to be uncorrelated with the explanatory variables.

The parameters of interest are $\alpha_{1}, \alpha_{2}$, and $\alpha_{3}$, the coefficients of the interaction between AFTER and $E L_{i}$. The interpretation of $\alpha_{1}$ is the difference between the change in the propensity to sign a new loan during the 1998 and 2001 periods for eligibles for class 1 subsidy and the corresponding change for non-eligibles. Given the discussion in the Section 3, we expect $\alpha_{1}, \alpha_{2}$, and $\alpha_{3}$ to be negative.

Model (1) uses the time variation between 1998 and 2001 for the three eligible groups to identify the effects of changes in the interest rate on the probability of signing a new loan over time. As discussed in Section 3, Model (1) restricts the responses to the 1999 reform to be uniform within eligibles, that is not a suitable specification. As a consequence, we also estimate the following specification:

\footnotetext{
${ }^{26}$ We decided to pool together eligibility groups III and IV. The reason is that there is a relatively small number of individuals who signed loans in these classes.
} 


$$
\begin{aligned}
1\left(D_{i t}>\right. & 0)=\beta_{0}+\delta_{1} E L_{-} 1_{i} * H_{-} P_{i} * A F T E R_{t}+\delta_{2} E L_{-} 2_{i} * H_{-} P_{i} * A F T E R_{t} \\
& +\delta_{3} E L_{-} 3_{i} * H_{-} P_{i} * A F T E R_{t}+\sum_{j=1}^{j=3} \beta_{i} E L_{-} J_{i}+\beta_{4} A F T E R_{t} \\
& +\beta_{5} H_{-} P_{i}+\sum_{j=1}^{j=3} \beta_{5+i} E L_{-} J_{i} * A F T E R_{t}+\sum_{j=1}^{j=3} \beta_{8+i} E L_{-} J_{i} * A F T E R_{t} \\
& +\sum_{j=1}^{j=3} \beta_{11+i} E L_{-} J_{i} * H_{-} P_{i}+\beta^{\prime} X_{i t}+\theta_{i}+\eta_{i t}
\end{aligned}
$$

$H_{-} P_{i}$ denotes that the county of residence of the individual is "high-price." We define counties with high prices as those in which the average price of traded dwellings in 1998 was above the country mean, 83,282 euro. To avoid biases caused by individuals moving to a low price region in response to the reform, we use the county of residence one year prior to the interview (that is, one year before getting the loan.) ${ }^{27}$ The specification in model (2) uses three sources of variation to identify the effects of changes in interest rate on the probability of signing a new loan. First, it exploits the time variation from the reform of the program. Second, model (1) uses the variation in interest rate subsidies across eligible groups and, finally, it permits differential effects for high-price counties. The coefficients of interest are $\delta_{1}$, $\delta_{2}$ and $\delta_{3}$. For example, $\delta_{1}$ measures the difference in the change in the propensity to borrow during 1998 and 2001 between eligibles for the maximum subsidy living in high-price counties and ineligibles in the same counties, net of the same trend among individuals living in low price counties.

There is an issue regarding the exogeneity of some of the covariates: the same set of unobserved characteristics may lead individuals to get a mortgage and establish their own household, for example. To assess the robustness of our results to possible endogeneity of the covariates, we estimate three alternative specifications for each model: one without covariates,

\footnotetext{
${ }^{27}$ There could still be a problem with individuals responding in the 2001 wave, if they moved in 1999 or 2000, for example. For those individuals, the county of residence one year before getting the loan in 2001 may itself be a response to the reform. We think that the restrictions in our sample mitigate that potential problem. Individuals who have moved recently are likely to have a mortgage to purchase a new house. We restrict the individuals in our sample to have zero debt holdings prior to getting a loan, who are less likely to have moved in the year before the interview.
} 
another with a small set of what we consider "safe" covariates (education dummies, variables related to eligibility, such as family size, and a third-order polynomial in age) and a final specification with a full set of covariates, including county fixed-effects.

\subsubsection{The debt amount}

We also present evidence of the evolution of the debt amount. The model estimated is the following:

$$
\begin{aligned}
I_{i t}^{*}= & \gamma_{0}+\gamma_{1} E L L_{-} 1_{i} * A F T E R_{t}+\gamma_{2} E L L_{-} 2_{i} * A F T E R_{t}+\gamma_{3} E L L_{-} 3_{i} * A F T E R_{t} \\
& +\gamma_{5} A F T E R_{t}+\sum_{j=1}^{j=3} \gamma_{5+j} E L_{-} J_{i}+\alpha^{\prime} X_{i t}+\varepsilon_{1 i t} \\
\ln d_{i t}= & \beta_{0}+\beta_{1} E L \_1_{i} * A F T E R_{t}+\beta_{2} E L \_2_{i} * A F T E R_{t}+\beta_{3} E L_{-} 3_{i} * A F T E R_{t} \\
& +\delta_{5} E L_{-} 1_{i}+\delta_{6} E L \_2_{i}+\delta_{7} E L_{-} 3_{i}+\delta^{\prime} X_{i t}+\varepsilon_{2 i t} \quad \text { if } \quad I_{i t}^{*}>0
\end{aligned}
$$

where $I_{i t}^{*}$ is a latent variable indicating the individual's $i$ desire to borrow at moment t. $\ln d_{i t}$ is the logarithm of the amount of new long-term debt signed by the individual, which is observed only if $I_{i t}^{*}$ is positive. $X_{i t}$ denotes the same set of demographic variables as in the previous specification. $\varepsilon_{1 i t}$ and $\varepsilon_{2 i t}$ are distributed normally with correlation $\rho$. Separate identification of the equations is achieved through functional form, although we also experimented with exclusion restrictions based on competition measures. ${ }^{28}$ As in the previous specifications, the coefficients of interest are $\beta_{1}, \beta_{2}$, and $\beta_{3}$. The interpretation of $\beta_{1}$ is the percent change in the average amount of new long-term debt between an individual eligible for the maximum subsidy who chooses to acquire long-term debt after the 1998 reform and another individual with the same characteristics who chooses to acquire prior to the reform. ${ }^{29}$

\footnotetext{
${ }^{28}$ We experimented including in the selection equation: number of bank agencies and number of banks in the NUTS-III level. The identifying assumption in that specification is that banks compete for customers at the NUTS-III level, and increased competition raises the availability of debt, but that, conditional on prices of houses, increased competition does not affect the amount of mortgage desired.

${ }^{29}$ This interpretation can be viewed as supported by a structural model in which $I_{i t}$ denotes the marginal utility of borrowing net of costs, and $\log d_{i t}$ is the desired amount of debt. See Angrist (2001) for a critical review of the assumptions in this model.
} 
If the removal of the subsidy had any effect on the desired amount of debt, the sign of the coefficients $\beta_{1}, \beta_{2}$, and $\beta_{3}$ would be negative.

\section{Empirical evidence}

\subsection{Experiments using variation across eligible groups and time}

Columns (1) through (3) in Table 3 present a simple differences-in-differences analysis with the proportion of borrowers. The estimate in Column 1, row 2 is .045. It suggests that the probability of signing a loan in a given year, for an individual eligible for the maximum subsidy, prior to the reform was 4.5 percent. That probability rose to 6.3 percent after the reform (Column 1, row 1). The increase after 1999 was .018 (Column 1, row 3), very similar to the corresponding number for non-eligibles, 1.6 percent (Column 2, row 3). The differencesin-differences estimate is .002, positive, small and non-significantly different from zero. ${ }^{30}$ Yet, as discussed in Section 3, the diffs-in-diffs evidence is not the most appropriate specification to test for the impact of the 1999 reform on the probability of holding debt, as it is constraining the effects of the reform to be constant among groups that are affected and others that are not (groups living in "high-" and "low-" price regions, respectively.)

Columns (4) through (6) in Table 3 present a simple difference-in-difference analysis of the average amount of initial debt, exploiting two sources of variation to identify the effect of the CB program. Panel A shows the difference between an average individual debt for eligible group 1 and non-eligibles before and after the reform. Each cell contains the average debt within the eligibility group, including individuals who do not have debt. For eligibles, the difference between the post- and pre-reform initial debt is 238 euros (Column 4, row 3). The corresponding difference for the non-eligible group is 844 euros (Column 5, row 3). Hence, even though eligibles as a group signed slightly higher initial loans, the increase was smaller than the increase for non-eligibles, who were not affected by the reform. Panels B and C present the comparison between the average initial loans for the other classes of eligibles and non-eligibles. These results are consistent with negative, significantly different from zero

\footnotetext{
${ }^{30}$ The basic results in Table 3 of the response of the probability of signing a new loan to changes in the interest rate do not change when we introduce covariates. For brevity, we do not include the estimates of OLS and Probit models.
} 
effects of the reform on the amount of initial long-term debt. Nevertheless, these results mix both the impact on the probability of signing new debt and the amount of initial debt signed.

\subsection{Experiments using variation across eligible groups, time and county}

This subsection presents the results of estimating model (2). That specification allows for different responses to the change in interest rates for individuals living in high and low price counties.

The first column of Table 5 shows OLS estimates of model (2) without adding additional covariates $X$. The constant term is the pre-reform probability of signing a new loan among non-eligibles in high-price counties. The coefficient of the interaction between $E L I G \_1$, AFTER and HIGHPRICE in the first column is -.052. The standard error, corrected for heteroskedasticity and arbitrary correlation within observations from the same individuals is $.029 .{ }^{31}$ The magnitude of the coefficient implies a 5.2 percent fall of the probability of signing a new loan among individuals eligible for the maximum subsidy who were living in high price regions one year before signing the loan. The results for the first eligible group do not change substantially when we include additional covariates (columns (2) and (3).) The corresponding estimate of the coefficient of the interaction between $E L I G \_2, A F T E R$ and HIGHPRICE is -.10 (standard error: .042). The estimate is significantly different from zero at the 2 percent confidence level. The magnitude of the OLS coefficient for the second group suggests a relative fall of $10 \%$ in the probability of signing a new loan among eligibles for the $16 \%$ subsidy. The magnitude of the coefficient is larger than in the previous case. The result is somewhat surprising, given that according to the computations in Table 1, the eligibility group 2 was exposed to an increase in the interest rate of 16 percent of interest rate payments, while the first group was exposed to a 24 percent increase. A possible explanation is that individuals eligible for the class 1 subsidy are more likely to adjust in high price counties by

\footnotetext{
${ }^{31}$ We include a correction for autocorrelation within observations from the same individual. Bertrand, Duflo and Mullainathan (2002) argue that, due to autocorrelation in the treatment and outcome variables, standard errors should allow for autocorrelation within treatment units. The time period we use is relatively short, four years, hence we do not include further corrections than individuals. Correcting for arbitrary correlation within counties instead of individuals increases the estimated standard errors of the variables of interest by 10 percent.
} 
purchasing houses at the ceiling than eligibles for class 2 , as they have less income on average. An alternative explanation is that individuals eligible for the highest subsidy are more likely to be liquidity constrained than individuals eligible for the class 2 subsidy. Hence, their borrowing behavior is less responsive to changes in the interest rate than that of higher income groups. ${ }^{32}$ Finally, the estimate in column (1) for ELIG_3, AFTER and HIGHPRICE is negative, imprecise and not significantly different from zero. The point estimate suggests a 4 percent fall in the probability of signing a new loan, a similar magnitude to the point estimate for group 1 .

Column (4) in Table 4 is a Probit specification. The coefficient of ELIG_1*AFTER* HIGH PRICE denotes the differential change in the probability of signing a new loan between an eligible individual in a high-price county and another individual in a low-price county, holding the rest of the covariates at their average. The magnitude of the coefficient suggests a 2.5 percent fall in the probability of signing a new loan, and the standard error is .017. The effect is significant at the $12 \%$ confidence level. The pattern for the second eligibility group is also smaller than in the OLS specification -.051 (standard error: .013,) significantly different from zero at the 1 percent confidence level. These magnitudes almost halve those implied by the OLS results. To further assess the extent to which non-linearities and the point chosen to evaluate the probability in the Probit specification are driving the discrepancy in the estimates, we have constructed the parameter reported in the OLS specification.

$$
\begin{aligned}
\gamma & =\left[\Delta_{\text {elig_high }} P(D=1 \mid E L I G, P R I C E, A F T E R)-\right. \\
\Delta_{\text {non_el_high }} P(D & =1 \mid E L I G, P R I C E, A F T E R)]- \\
{\left[\Delta_{\text {elig_lowprice }} P(D\right.} & =1 \mid E L I G, P R I C E, A F T E R)- \\
\Delta_{\text {non_el_lowprice }} P(D & =1 \mid E L I G, P R I C E, A F T E R)]
\end{aligned}
$$

In this expression, for example, $\Delta_{\text {elig_high }} P(D=1 \mid E L I G, P R I C E, A F T E R)$ denotes the difference between the pre- and post-reform probabilities of signing a new loan for eligible

\footnotetext{
${ }^{32}$ Attanasio et al. (2000) illustrate in a durable good context that the elasticity of the amount borrowed by liquidity constrained households to changes in the interest rate is smaller in absolute value than that of households with free access to the debt market. Jappelli (1990) provides evidence from the US that households headed by younger individuals with low income are more likely to be denied credit.
} 
individuals in high price counties. The probabilities $P(D=1 \mid E L I G, P R I C E, A F T E R)$ are constructed using a Probit specification, and the standard errors are calculated using the delta method. For class 1, we have a value of the parameter of -..055 in a specification without covariates (standard error: .03). The corresponding estimate for group 2 is -.11 (standard error: .04). These magnitudes are very similar to the OLS result presented in the first column of Table 7. Once we compute comparable estimates, the Probit and OLS methods in estimating model (2) yield similar estimates of the effect of the reform on the probability of holding debt.

To further quantify the relationship between interest rates and the probability of signing a new loan, we have run the following regression:

$$
\begin{aligned}
& 1\left(D_{i t}>0\right)=\delta_{0}+\delta_{1} \ln \left(I N T T_{-} \text {RATE } E_{i t}\right)+ \\
& \sum_{j=1}^{j=3} \beta_{i} E L_{-} J_{i}+\beta_{4} A F T E R_{t}+\beta_{5} H_{-} P_{i}+\sum_{j=1}^{j=3} \beta_{5+i} E L_{-} J_{i} * A F T E R_{t} \\
& +\sum_{j=1}^{j=3} \beta_{8+i} E L_{-} J_{i} * A F T E R_{t}+\sum_{j=1}^{j=3} \beta_{11+i} E L_{-} J_{i} * H_{-} P_{i}+\beta^{\prime} X_{i t}+\theta_{i}+\eta_{i t}
\end{aligned}
$$

In the expression above, INT_RATE $E_{i}$ denotes the interest rate. We assume that all individuals face the same pre-subsidy interest rate of $8 \%$, and that the subsidy is applied to all eligible individuals. Finally, we assume that only eligible individuals living in high price regions lost access to the subsidy. The expression above implicitly constrains the response of borrowing behavior to the change in the interest rate to be constant across eligible groups. The parameter of interest is $\delta_{1}$, which measures the response of the probability to borrow to a percentage increase in the interest rate. The estimate from that specification is -.16 (standard error: .09). It is significantly different from zero at the 8 percent confidence level. Given that the probability that an eligible in a high price county signed a loan prior to the reform was 5.5 percent, the estimate translates into an elasticity of 2.9. At face value, the estimate is large, compared to evidence on other types of debt. Gross and Souleles (2002) and Alessie et al. (2001) find elasticities of short-term debt amount to the interest rate of 1.3. Gary-Bobo and Larribeau (2003) use a sample of mortgage loans in France, and estimate the elasticity of the mortgage amount to the interest rate between 2 and 2.7, closer to our estimate. Yet, 
the studies mentioned analyze the response of the debt amount to the interest rate, which is likely to be less responsive to interest rate changes than the probability of getting new debt. Poterba (2001) summarizes the evidence on the responses household portfolios to tax incentives and that the extensive margin is more responsive to changes in after-tax returns than the intensive margin.

Our results also differ from other recent research from Europe. For example, Jappelli and Pistaferri (2002), exploit a tax reform in Italy between 1992 and 1994 that increased the aftertax interest rate for high-income households and reduced it for low income-households and do not find evidence that changes in the incentive to borrow affect the probability of getting a mortgage. We find two explanations for the divergence between their results and ours. The first is the availability of information about the program. Jappelli and Pistaferri stress that Italian households lack financial sophistication. Conversely, the CB program involved the participation of banks, which are informed agents, and could advise their customers about the availability of the program. The second explanation is related to the difference in the datasets, as JP restrict themselves to heads of households, and use indicators of whether the individual holds any debt, rather than if the individual signed a new loan in the period. We ran model (2) using a dependent variable that takes value 1 if the individual holds long-term debt and zero otherwise. The coefficients were negative, imprecise, and not significantly different from zero.

Table 5 presents some sensitivity results. In Column 1, we include individuals living in counties for which we could not obtain the increase in prices between 1998 and 2001. We assigned an increase in the prices of $17 \%$, the country average for the period. In Column 2 , we raise the minimum loan to 7,500, rather than 5,000. Finally, in Column 3 we recompute eligibility excluding from the computation of family size children between 1 and 2 years of age. The idea is to avoid strategic fertility decisions in 1998 to qualify for the program. The results in these specifications are similar to our baseline specification.

\subsubsection{Effect on co-residing adults}

The Portuguese housing market shares common features with other Southern European markets, like a low percentage of young individuals living in rented houses, and a substantial 
fraction of young households co-residing with their parents. ${ }^{33}$ The availability of parental help through housing services can make young adults able to delay "nest-leaving" in response to changes in the interest rate, so that their elasticity of borrowing decisions to its price is specially large. Conversely, older adults may have a demand for housing services and borrowing decisions that responds to demographic variables, like family size. In Table 6, we run OLS regressions for the restricted subsample of individuals who reside with their parents. The results suggest that the 1999 reform affected more the borrowing behavior of individuals residing with their parents. For the group eligible for the maximum subsidy, the relative proportion of borrowers in high-price counties fell by almost 11 percent (significantly different from zero at the 5 percent level.) The results for the other groups are in that order of magnitude, but more imprecise, as the number of loans for those groups is relatively small. Hence, within individuals eligible for the maximum subsidy, the effects of the 1999 reform seem to be concentrated among co-residing adults. ${ }^{34}$

\subsection{Other results: The amount of debt}

Next, we analyze the effect of the interest rate reduction on the amount of debt signed. We expect the 1999 reform to reduce the amount of debt among eligibles, as this group now faces the choice between financing the purchase of a house with market value above the ceiling and buying a cheaper house financed by a CB loan. Even if the response of the demand for housing services to the interest rate is zero, the presence of a ceiling may induce individuals to reduce their demand for housing services to gain access to the CB program.

Table 7 presents estimates of model (3) using both ordinary least squares on the sample of individuals who have signed a loan during the year of the interview. Given that an OLS specification does not take into account the truncation in the dependent variable, we also report coefficients from a Maximum Likelihood specification. ${ }^{35}$ The interpretation of the

\footnotetext{
${ }^{33}$ See Manacorda and Moretti (2001), or Martínez-Granado and Ruiz-Castillo (2002) for evidence about co-residence in Italy and Spain, respectively.

${ }^{34}$ We have also split the sample by age, namely by principal earners younger than 35 and principal earners older than 35. The results (not shown) suggest that the change in the interest rates had greater effects for individuals below age 35 .

${ }^{35}$ Following most of the literature on wealth and savings, we choose a specification in logarithms. The reason is that interest rates were falling for most of our sample period. Given that the average debt varied across groups (see Table III), a specification in levels can lead to a spuriously negative effect of the reform. Assume
} 
coefficient of ELIG_1*AFTER $R_{t}$ is the percentage difference in the change in the amount of initial long-term debt of eligible individuals who choose to acquire new debt, relative to the change in the same amount held by non-eligibles, holding constant the set of covariates presented in Table 4. Our preferred specification in Table 7 is the estimation of model (3) by Maximum Likelihood, which is reported in the second column. The point estimate of the coefficient of ELIG_1*AFTER $R_{t}$ is -.32 (standard error: .13,) suggesting that among eligibles for the maximum subsidy, the initial loan amount diminished by $32 \%$ with respect to non-eligibles. The estimate of $E L I G \_1 * A F T E R_{t}$ in column (1) of Table 9 shows virtually identical results in an OLS specification. The coefficient of ELIG_2*AFTER $R_{t}$ in the second column of Table 7 implies a percentage reduction in the average amount of debt of 49 percent. The point estimate is -.496( standard error: .20) is larger than for the first group. The point estimate for the combined third and fourth eligibility groups is positive and not significantly different from zero.

Columns (3) and (4) of Table 7 allow for different responses across high- and low- price counties. In the OLS specification, the coefficient of the interaction between ELIG_1* AFTER $R_{t} * H I G H P R I C E$ is .098 (standard error: .27). We do not find evidence for a relative fall in the amount of debt signed by eligibles in high price counties. A possible explanation for this result is that most individuals in low price counties responded to the reform by purchasing houses at the ceiling set by the 1999 reform, while in high price counties, a share of individuals responded by purchasing houses at the ceiling (and hence reducing their initial debt) and another share of individuals chose not to purchase.

\section{Robustness Checks}

\subsection{Falsification exercises.}

Even if the 1998 reform had no effects on the propensity to borrow, the coefficients in model (2) could pick up differential trends in borrowing behavior between eligibles and non-eligibles

that the program has no effect and that, in response to a fall in the interest rate, all households increase their debt by a fixed percentage. A specification in levels would find lower growth in the amount of debt among eligibles, suggesting a negative effect of the reform. See Engen and Gale (2000) for a similar reasoning when evaluating whether $401(\mathrm{k})$ programs have increased savings in the US. 
in high price areas. Throughout the late 1990s, the banking industry in Portugal became more competitive, especially in high-price areas (Standard and Poor's ratings direct report, 2002). The increase in competition may have created a different trend in high-price areas if banks competed to offer debt to high-income individuals, most likely to be ineligible for the CB program.

To examine whether or not any pre-existing differential trend underlies our results, we created a "fake" reform in 1998. For this exercise, we used the 1998 and 1999 waves of the IE, plus additional information on the CRC debt. In principle, we have only four quarterly surveys of pre-reform data. (the four surveys in 1998). Yet, we know the history of debt of individuals from 1995. Hence, we can establish whether or not an individual interviewed in the 1998 wave signed a loan during the 1997 wave. We can also establish whether or not an individual interviewed in the 1999 wave signed a loan during the 1998 wave. In order to establish if these individuals qualified for the CB loan at the time of signing the loan, we recomputed eligibility at that time. We can establish family size in the previous year using information on the dates of birth of the members of the family and not counting members born by the time of the period in which the loan was subscribed. As for income, we do not know the value of income at the time of the interview. Hence, we deflated current income using the growth rate in the minimum wage in Portugal.

Next, we ran another version of model (2), but now assigning a value of 1 to the variable $A F T E R_{t}$ if the loan was signed in 1998, when the CB program did not impose any restriction on the value of the house purchased. The interaction between $E L I G \_1, A F T E R$ and HIGHPRICE should pick up any differential pre-reform trend in the borrowing behavior among eligibles. The second column in Table 8 shows the OLS estimates of that model. The coefficient of the interaction between ELIG_1, AFTER and HIGHPRICE is -.012 (.019). It is not significantly different from zero at any popular confidence level. The corresponding coefficient in Table 4 was -.055, with a standard error of .029. The coefficient of the interaction between ELIG_2, AFTER and HIGHPRICE is .008 (the standard error is .03.) A non-linear Probit specification shows estimates for the first group that range between .009 (standard error: .009) and .011 (standard error: .01). From this evidence, we interpret that 
pre-existing trends are not likely to drive the results in Table $4 .^{36}$

\subsection{Did the CB program affect real estate prices?}

Subsidies to housing are often criticized for resulting in higher prices of real estate without increasing home ownership. The reason is that the supply in this market is either inelastic (Glaeser and Shapiro, 2002) or adjusts slowly (Poterba, 1984). In the previous analysis, we have focused on a demand-side analysis, but the CB program could have resulted in increases in real estate prices, especially in the type of housing demanded by eligibles. In this section, we discuss the impact of the CB program on real estate prices in two different ways. First, we discuss the aggregate relationship between measures of use of the CB program and the evolution of real estate prices. Second, we examine the county-level relationship between the evolution of real estate prices in the 1995 - 1998 period and eligibility for the CB program.

Figure 3 presents the steady increase in the quality-unadjusted price of real estate from 1989 to the end of 2001. First, while this period coincides with the expansion of the CB program, it must be taken into account that the interest rate also fell steadily during the decade, and per capita income increased. Second, according to Figure 1, the period of higher increase in the value of new debt corresponds to relatively moderate increases in the real estate prices. From 1995-1998, the amount of new loans increased at an average annual rate of 41 percent, while the average yearly increase for the 1991-2001 period was 32 percent. On the other hand, real estate prices increased at an annual rate of 6.2 percent over the 1990-2001 period and 3.2 percent during the 1995-1998 period. Moreover, after the 1999 reform, the real estate prices continued to increase despite the decrease in the value of total loans, which is not consistent with the assumption of a rigid supply of real estate. Figure 3 documents an annual increase of 6.4 percent in real estate prices during the 1999 to 2001 period, while, as highlighted in Figure 1, there was a significant decrease in the annual amount of new loans

\footnotetext{
${ }^{36}$ Another potential problem is a mechanical differential trend between non-eligibles and eligibles. Assume that we observe single individuals living with their parents, being eligible for the program, and with no mortgage. These individuals marry, pool incomes, becoming non-eligible, and get a mortgage. The reform could not have any effect, but still we would observe a negative trend among eligibles. We followed the same strategy above, to detect any pre-reform trend between eligibles and non-eligibles as a group. The coefficient estimate for the interaction of ELIG_1, AFTER and HIGHPRICE was -.01 (standard error: .008). The corresponding interactions for groups 2 and 3 were -.01 (.014) and .01 (.015), respectively.
} 
after the reform (the amount of new loans decreased by 12.7 percent in 2000 and by 5.6 percent in 2001).

The previous analysis reflects only country trends, and does not quantify the relationship between real estate and the use of the CB program. We have analyzed the relationship between eligibility for the CB program pre-reform and the increase in the price of real estate between 1995 and 1998 - the years of expansion of the CB program, using variation in the proportion of eligibles across counties. Our identifying assumption is that if the CB program had an impact on the prices of real estate, counties with a higher proportion of eligibles should experience overall higher growth in house prices, holding income of the county constant. Using information on 86 counties, we do not find that the proportion of eligibles in the county affects the increase in real estate prices. ${ }^{37}$

In summary, we interpret that regional variation in eligibility does not seem to explain differences in the increase of real estate prices. We infer that the increase in housing prices from the 1990-2001 has been general across all counties, independently of the proportion of the eligible group of individuals living in a particular county. Hence, our strategy of allowing for a time trend should capture the effect of the increase in prices.

\section{Conclusions}

In this paper we have used matched data on administrative records of individual debt and survey data to estimate the effect of changes in the mortgage interest rate on long-term household borrowing. Our identification strategy relies on the reform of a large program that subsidized loans to young and low income individuals. That reform introduced a ceiling in the price of the house that could be financed through the program, and we argue that it created

\footnotetext{
${ }^{37}$ The results of the regression were the following (standard error of the estimated coefficients in parentheses). The number of observations was 86 . The $\mathrm{R}^{2}$ of the regression is 0.38 . In the regression PELIG_1 represents the ration between the eligibility of class 1 and the non-eligibles, in the county (we have also ran alternative specifications using the proportion of the eligibility class in the county as regressors, and the results do not change much)

$$
\begin{aligned}
& \frac{P R I C E \_98}{P R I C E \_95}=-.005(.004) P E L I G \_1+.024(.040) P E L I G \_2+.07(.074) P E L I G \_3+.08(.069) P E L I G \_4 \\
& +.143(.069) I N C O M E-.004(.011) P O P U L A T I O N-.0003(.00007) * P R I C E \_95
\end{aligned}
$$
}


a discontinuity in the incentives to borrow among several groups of the population.

We have two main findings. The elasticity of the probability of mortgage borrowing to a change in the interest rate is large and negative: an increase in the interest rate of 1 percent reduces the probability of borrowing by 2.9 percent. That elasticity is higher for young adults residing with their parents. Second, we also find that the amount borrowed responds negatively to the change in the interest rate, although it is difficult to interpret the magnitude of the response. These results differ from previous studies using tax reforms. We argue that the sources of discrepancy may come from the widespread availability of information about the CB program we consider, but also differences in the quality of the data may matter.

Our results suggest that individual borrowing among groups at the margin of home ownership, such as the young and (relatively) low income individuals does respond to changes in the interest rate. Public programs that target these groups can be a powerful tool to increase access to long - term debt markets and shape their savings decisions. Our data cannot provide direct evidence of whether or not these programs actually increase total household saving. That is a line for future research.

\section{References}

[1] Alessie, R. Hochguertel, S. and Weber, G. (2001) "Consumer Credit: Evidence from Italian Micro Data," CEPR Discussion Paper no. 3071.

[2] Angrist, J. (2001) "Estimations of Limited-Dependent Variable Models with Dummy Endogenous Regressors: Simple Strategies for Empirical Practice," Journal of Business and Economic Statistics, 19, Iss. 1, 2-16.

[3] Attanasio, O., Goldberg, P., and Kyriazidou, E. (2000) "Credit Constraints in the Market for Consumer Durables: Evidence from Micro Data on Car Loans," NBER Working Paper no. 7694 .

[4] Bernheim, Douglas (2002) "Taxation and Saving," in Alan Auerbach and Martin Feldstein, Handbook of Public Economics. Amsterdam: North-Holland. 
[5] Bertrand, M., Duflo, E., and Mullainathan, S. (2002) "How Much Should We Trust Differences-in-Differences Estimates?," NBER Working Paper no. 8841.

[6] Devereux, M., and Lanot, G. (2003) "Measuring Tax Incidence: an Application to Mortgage Provision in the UK," Journal of Public Economics, 87, Iss. 7-8, 1747-1778.

[7] Engelhardt, G. (1996) "Tax Subsidies and Household Saving. Evidence from Canada," Quarterly Journal of Economics, 111, Iss. 4, 1237-1268.

[8] Engen, E. and Gale, W. G. (2000) "The Effects of 401(k) Plans on Household Wealth," NBER Working Paper no. 8032.

[9] Gary-Bobo, R., and Larribeau, S. (2003) “The Bank's Market Power and the InterestRate Elasticity of Demand for Housing: An Econometric Study of Discrimination on French Mortgage Data," CEPR Discussion Paper no. 3745.

[10] Gervais, M. (2002) "Housing Taxation and Capital Accumulation" Journal of Monetary Economics (49): 1461-1489.

[11] Glaeser, E. and Shapiro, M. (2002). "The Benefits of Home Mortgage Interest Deduction," Harvard Institute of Economic Research, Discussion Paper no. 1979.

[12] Gross D. and Souleles, N. (2002) "Do Liquidity Constraints and Interest Rates Matter for Consumer Behavior? Evidence from Credit Card Data," Quarterly Journal of Economics, 117, Iss. 1, 149-185.

[13] Henderson, J. V. and Ioannides Y. (1983) "A Model of Housing Tenure Choice," American Economic Review 73: 98-113.

[14] Jappelli, T. (1990) "Who Is Credit Constrained in the U.S. Economy?," The Quarterly Journal of Economics, 105, Iss. 1, 219-34.

[15] Jappelli, T. and Pistaferri, L. (2003) "Tax Incentives and the Demand for Life Insurance: Evidence from Italy," Journal of Public Economics, 87, Iss. 7-8, 1779-1799. 
[16] Jappelli, T. and Pistaferri, L. (2002) "Incentives to Borrow and the Demand for Mortgage Debt: An Analysis of Tax Reforms," Working Paper number 90, CSEF Working Papers, University of Salerno.

[17] Maki, D. (2001) "Household Debt and the Tax Reform Act of 1986," American Economic Review, 91, Iss. 1, 305-319.

[18] Manacorda. M, and Moretti E. (2001) "Intergenerational Transfers and Family Structure: Why Do Most Italian Youths Live With Their Parents?," UCLA, mimeograph.

[19] Martínez-Granado, M. and Ruiz-Castillo, J. (2002) "The Decisions of Spanish Youth: a Cross-Section Study," Journal of Population Economics 15, 305-330.

[20] Poterba, J. (2001) "Taxation and Portfolio Structure: Issues and Implications in Household Portfolios," Luigi Guiso, Michalis Haliassos and Tullio Jappelli (eds.), Cambridge MA: MIT Press.

[21] Poterba, J. (1984): "Tax Subsidies to Owner-Occupied Housing: An Asset Market Approach," Quarterly Journal of Economics, 99, Iss. 4, 729-752.

[22] Scholz, K. (1994) "Portfolio Choice and Tax Progressivity: Evidence from the Surveys of Consumer Finances," in J. Slemrod, (ed.), Tax Progressivity and Income Inequality (New York Cambridge Press).

[23] Standard and Poor's (2002) Research: Bank Industry Risk Analysis: Portugal

\section{Appendix A. Data appendix}

In this appendix we describe the construction of income variable and eligibility measures.

\section{A.0.1 Construction of pre-tax income}

Individuals are eligible if their adjusted pre-tax taxable income is below a certain threshold. For each quarter, the Inquerito ao Emprego asks each individual in the household about his or her labor income source, unemplyment benefit, income from self-employment and retirement income. 
The exact questions (for employed individuals) are:

- "What is the net monthly earnings in your main job (in Portuguese currency - escudos)"

- "What is the net amount on earnings additionally to your main job, received with a periodicity above the month, over the last 12 month"

For unemployed individuals:

- "What is the monthly net amount of unemployment benefits or other monthly welfare income (in euro)."

For retired individuals:

- "What is the monthly net amount of your pension (in euro)."

We converted monthly amounts into euro. If an individual reported several different earnings every quarter during the same year, we averaged them. To recover yearly income, we multiplied the amount by 14 . For income with periodicity over the month, we took the maximum reported over the year. For married couples, we added all available income measures of the head and spouse, but did not include the earnings of any other member. We infered gross income by using the fact that Social Security contributions amount to $11 \%$ of earnings in Portugal, and the standard withholding rules.

\section{A.0.2 Family size}

Next, we compute family size, adding up the number of individuals in the household, but excluding young adults who are sons or daughters of the head above age 18 and who report positive income. As mentioned in the text, these individuals may choose to file taxes individually. Their imputed family size is 1 .

\section{A.0.3 Eligibility}

To determine eligibility, the Credito Bonificado introduced a measure of "adjusted household income." A family of one member had its total yearly income multiplied by 1.3. The income of 
a two-person family was not corrected. A three-person family adjusted income by substracting 165,000 escudos (823 euro). The corresponding deductions for four, five and more than five member families was 330,000, 495,000 and 660,000 escudos, respectively.

Families were eligible for the maximum subsidy if their adjusted yearly income exceeded 3.25 times the minimum yearly wage, which was obtained by multiplying the minimum monthly wage by 14 . The minimum monthly wage in Portugal was 293.79 euro in 1998, 305.76 euro in 1999, 318.23 euro in 2000 and 334.19 euro in 2001.

\section{Appendix B. Theory appendix (not intended for publication)}

This appendix proves the claims made in Section 3. The first claim states that because of the ceiling introduced by the 1999 reform, the comparison of the evolution of borrowers before and after the reform, holding prices constant, underestimates the effect of a change in the interest rate on the probability of borrowing. First, we characterize the determinants of the choice to borrow using a specific utility function. Second, we analyze the possible responses to a change in the budget constraint like that in the 1999 reform (which can be observed in the data.) Finally, we relate both magnitudes. The second claim states that, if the elasticity of expenditure in housing services with respect to the price $p$ is positive, the introduction of a ceiling affects a larger share of consumers in high price regions than in low-price regions.

Let us assume the following preferences of the consumer:

$$
U\left(c_{1}, h, c_{2}\right)=\frac{c_{1}^{1-\rho}}{1-\rho}+\gamma \frac{h^{1-\sigma}}{1-\sigma}+\frac{c_{2}^{1-\rho}}{1-\rho}
$$

$c_{1}$ denotes first period consumption, $h$ housing services and $c_{2}$ second period consumption. $\gamma$ measures the (relative) preference for housing services. We further assume that $\sigma>\rho>1$. The consumer receives an exogenous amount of income $y_{1}$ in the first period, and $y_{2}$ in the second. In the first period, the consumer may choose whether or not to acquire housing services $h$ at a price per unit $p$. If the consumer does not acquire housing services, he or she enjoys a consumption level of $\bar{h}$ We ignore depreciation or revaluation of the housing stock, as well as other ownership costs, so an investment in a unit of housing today is worth $p$ in the second period. The consumer can ask for a loan $m$ for each unit of housing services, at an 
interest rate $r$, and $m$ cannot exceed $p$. The first-period budget constraint is the following

$$
c_{1}+s+(p-m) h=y_{1}
$$

$s$ denotes savings. It can be shown that the consumer cannot borrow and lend at the same time. The second-period budget constraint is the following

$$
c_{2}+(1+r) h m=y_{2}+p h+s(1+r)
$$

$r$ denotes the interest rate, and $y_{2}$ is second period income. Combining both budget constraints, one can get the expression for the budget constraint in Section 3. Finally, we assume that $\gamma$ is distributed continuously in the interval $[\underline{\gamma}, \bar{\gamma}]$ with a density function $d F(\gamma)$. Maximizing the utility function subject to the (linear) budget constraint (BC), one can get the optimal amount for the consumption of housing services, $h^{*}$, of period $1 \operatorname{good} c_{1}^{*}$ and period 2 good $c_{2}^{*}$. The demand for housing services can be obtained from the following implicit function.

$$
\left(\frac{h^{\sigma}}{\gamma}\right)^{\frac{1}{\rho}}(p r)^{\frac{1}{\rho}}\left(1+(1+r)^{-\frac{1}{\rho}}+\frac{p r}{1+r} h=y_{1}+\frac{y_{2}}{1+r}\right.
$$

Hence, $h^{*}=h\left(\gamma, r, p, y_{1}+\frac{y_{2}}{1+r}\right)$ differentiating the expression, one can obtain the following comparative statics: $\frac{\partial h^{*}}{\partial \gamma}>0, \frac{\partial h^{*}}{\partial r}<0$ and $\frac{\partial h^{*}}{\partial p}<0$. The optimal demand for mortgage debt $\left(m^{*} h^{*}\right)$ can be expressed as

$$
m^{*} h^{*}=\frac{\left(y_{2}+p h^{*}\right)+(1+r)^{\frac{1}{\rho}}\left(p h^{*}-y_{1}\right)}{\left(1+r+(1+r)^{\frac{1}{\rho}}\right)}
$$

It can be shown that an increase in $y_{1}$ coupled with a fall in $\frac{y_{2}}{1+r}$ that keeps $y_{1}+\frac{y_{2}}{1+r}$ constant reduces $m^{*} h^{*}$. Hence, if $y_{1}$ is sufficiently small compared to $y_{2}$ the individual will borrow. Throughout the appendix, we assume that this is the case, so we focus the analysis on individuals who purchase a house borrowing in the mortgage market. We also drop $y_{1}, \frac{y_{2}}{1+r}$ as arguments of the optimal choices. Also, $\frac{\partial\left(h^{*} m^{*}\right)}{\partial r}<0$ provided that $\rho>1$ The utility from not participating in the housing market is 


$$
\bar{U}_{\gamma}=\frac{\left[y_{1}-s\right]^{1-\rho}}{1-\rho}+\gamma \frac{\bar{h}^{1-\sigma}}{1-\sigma}+{\frac{\left[y_{2}+s(1+r)\right]^{1-\rho}}{1-\rho}}^{-\rho}
$$

Where the subscript $\gamma$ indexes the different utility levels of individuals with different values of $\gamma$ and $s$ can only be positive under our assumptions. The indirect utility function associated to participating in the housing market is the following:

$$
V_{\gamma}\left[\frac{1}{1+r}, \frac{p r}{1+r}, y_{1}+\frac{y_{2}}{1+r}\right]=\frac{\left(c_{1}^{*}\right)^{1-\rho}}{1-\rho}+\gamma \frac{\left(h^{*}\right)^{1-\sigma}}{1-\sigma}+\frac{\left(c_{2}^{*}\right)^{1-\rho}}{1-\rho}
$$

The consumer chooses to participate in the housing market and borrow only if, for given values of $\gamma, p$ and $r, \bar{U}<V_{\gamma}\left[\frac{1}{1+r}, \frac{p r}{1+r}, y_{1}+\frac{y_{2}}{1+r}\right]$

For individuals who borrow, the event $\left(\bar{U}_{\gamma}<V_{\gamma}\left[\frac{1}{1+r}, \frac{p r}{1+r}, y_{1}+\frac{y_{2}}{1+r}\right]\right)$ becomes less likely when $r$ increases. The reason is that $V_{\gamma}\left[\frac{1}{1+r}, \frac{p r}{1+r}, y_{1}+\frac{y_{2}}{1+r}\right]$ falls with the interest rate if the individual is a borrower. ${ }^{38}$ Conversely, if the consumer does not acquire housing services, an increase in the interest rate cannot decrease the utility, as under our assumptions, agents either save or consume their period income. The parameter of interest is the following.

$$
\frac{\partial P\left(m^{*} h^{*}>0\right)}{\partial r}=\int_{\underline{\gamma}}^{\bar{\gamma}} \frac{P\left(\bar{U}<V\left[\gamma, p, r_{p o s t}\right]\right)-P\left(\bar{U}<V\left[\gamma, p, r_{p r e}\right]\right)}{r_{\text {post }}-r_{\text {pre }}} d F(\gamma)
$$

Under the conditions above, for each $\gamma$ the term within the integral is negative. Hence, $\frac{\partial P\left(m^{*} h^{*}>0\right)}{\partial r}<0$. Now, the 1999 reform increased the interest rate only if the value of the purchased house exceeded a ceiling $(L)$. The after-reform budget constraint is

$$
c_{1}+\frac{c_{2}}{1+r_{p r e}}+\frac{r_{p r e}}{1+r_{p r e}} p h=y_{1}+\frac{y_{2}}{1+r_{p r e}} \quad \text { if } \quad h \leq \frac{L}{p}
$$

and

$$
c_{1}+\frac{c_{2}}{1+r_{\text {post }}}+\frac{r_{\text {post }}}{1+r_{\text {post }}} p h=y_{1}+\frac{y_{2}}{1+r_{\text {post }}} \quad \text { if } \quad h>\frac{L}{p}
$$

Let the values $h^{* *}, c_{1}^{* *}$ and $c_{2}^{* *}$ be the values that maximize B.1 subject to the (non-linear) 1999 budget constraint formed by $\mathrm{BC} 1$ and $\mathrm{BC} 2$. We denote the utility of consuming $L$ by

\footnotetext{
${ }^{38}$ Differentiating the indirect utility function with respect to $r$ and using Roy's identity, one gets $\frac{\partial V_{\gamma}}{\partial r}=$ $\left(c_{2}-p h-y_{2}\right) \frac{\partial V_{\gamma}}{\partial\left(y+\frac{g}{1+r}\right)}$. If the individual borrows, $\left(c_{2}-p h-y_{2}\right)$ is negative.
} 
$V^{c a p}$. In our data, we observe the equilibrium choices at the pre-reform interest rate, with a linear budget constraint, $P\left(m^{*} h^{*}>0 \mid \gamma, p, r_{p r e}\right)$ and the post-reform choices $P\left(m^{* *} h^{* *}>\right.$ $\left.0 \mid \gamma, p, r_{\text {post }}\right)$, with the non-linear budget constraints $\mathrm{BC} 1$ and $\mathrm{BC} 2 .{ }^{39}$ In the next claim, we relate these magnitudes to the parameter B.9.

Claim 1 Holding $p$ and the distribution of preferences constant, the comparison of borrowers before and after the 1999 reform underestimates the response of the probability of borrowing to a change in the interest rate.

- Let $\gamma_{0}$ be such that $h^{*}\left(\gamma_{0}, p, r_{p r e}\right)=\frac{L}{p}$. For $\gamma:\left[\underline{\gamma}, \gamma_{0}\right] h^{* *}\left(p, r_{p o s t}\right)=h^{*}\left(p, r_{p r e}\right)$. In other words, the post-reform choice of whether or not to participate in the housing market is the same as the pre-reform choice for individuals whose demand of housing services at the pre-reform interest rate is below the 1999 ceiling. Hence:

$$
\int_{\underline{\gamma}}^{\gamma_{0}} \frac{P\left(m^{* *} h^{* *}>0 \mid \gamma, p, r_{\text {post }}\right)-P\left(m^{*} h^{* *}>0 \mid \gamma, p, r_{\text {pre }}\right)}{r_{\text {post }}-r_{\text {pre }}} d F(\gamma)=0
$$

- Let $\gamma_{1}$ be such that $V_{\gamma}\left[\frac{1}{1+r_{\text {post }}}, \frac{p r_{\text {post }}}{1+r_{\text {post }}}\right]=V_{\gamma}^{\text {cap }} \cdot \gamma_{1}$ exceeds $\gamma_{0}$ because $h(\gamma, p, r)$ increases with $\gamma$ and decreases in $r$. For a subset of individuals whose $\gamma$ lies in the interval $\left[\gamma_{0}, \gamma_{1}\right]$ , the choice between participating in the housing market and not participating can be distorted toward going to the ceiling and not leaving the housing market. Namely, this group exists if parameters are such that $V_{\gamma}\left[\frac{1}{1+r_{\text {post }}}, \frac{p r_{\text {post }}}{1+r_{\text {post }}}\right]<\bar{U}<V_{\gamma}^{\text {cap }}$.

Hence, for $\gamma \in\left[\underline{\gamma}, \gamma_{1}\right]$ the observed $\frac{P\left(m^{* *}>0 \mid \gamma, p, r_{p o s t}\right)-P\left(m^{*}>0 \mid \gamma, p, r_{p r e}\right)}{r_{p o s t}-r_{p r e}}$ is a lower bound of $\frac{\partial P(m h>0)}{\partial r}$

- Finally, for individuals for whom $\gamma \in\left[\gamma_{1}, \bar{\gamma}\right], h^{*}\left(p, r_{\text {post }}, \gamma\right)>\frac{L}{p}$ and $V_{\gamma}\left[\frac{1}{1+r_{\text {post }}}, \frac{p r_{\text {post }}}{1+r_{\text {post }}}\right]$ $>V^{\text {cap }}$ the choice between participating in the housing market and not participating is not affected by the introduction of a ceiling.

\footnotetext{
${ }^{39}$ We keep the following convention. An asterisk * over a control variable denotes that it solves the problem of maximizing the utility function subject to the linear budget constraint BC (at either interest rate $r_{p r e}$ or $r_{\text {post }}$. Two asterisks denote that it maximizes the utility function subject to the non-linear budget constraint $\mathrm{BC} 1$ and $\mathrm{BC} 2$
} 
Claim 2 If $\sigma>\rho$, and the distribution of the parameter $\gamma$ is the same in a low and in a high- price region, the introduction of a ceiling to qualify for the subsidy makes case 1 more likely in a low price region.

Assume we have two regions. In region 1, the price of the real estate is $p_{\text {low }}$. In region 2 , the price is $p_{\text {high }}$ Assume also that in both regions, the same preferences $\gamma$ are distributed according to the same distribution function $d F(\gamma)$. Also, all individuals face the same interest rate $r$ First, if $\sigma>\rho$, then the derivative of housing services with respect to the price of real estate is negative and bigger than minus one. That result can be obtained differentiating B.4, that yields:

$$
-\frac{\partial h}{\partial p}=\frac{\frac{h r}{1+r}+\frac{1}{\rho} p^{\frac{1}{\rho}-1} r^{\frac{1}{\rho}}\left[1+(1+r)^{-\frac{1}{\rho}}\right]\left(\frac{h^{\sigma}}{\gamma}\right)^{\frac{1}{\rho}}}{\frac{p r}{1+r}+\frac{\sigma}{\rho}(p r)^{\frac{1}{\rho}}\left[1+(1+r)^{-\frac{1}{\rho}}\right] \gamma^{-\frac{1}{\rho}} h^{\frac{\sigma}{\rho}-1}}
$$

As long as $\sigma>\rho, 0<-\frac{p}{h} \frac{\partial h}{\partial p}<1$, and $\frac{p}{p h} \frac{\partial p h}{\partial p}>0$. (a positive elasticity of the expenditure in housing services with respect to the price $p$.) Given two identical individuals with the same preferences for housing $\gamma$, the individual in region 2 spends a larger share of her budget in housing than the individual in region 1 , that is, $p_{\text {high }} h^{*}\left(\gamma, p_{\text {high }}, r_{\text {pre }}\right)>p_{\text {low }} h^{*}\left(\gamma, p_{\text {low }}, r_{\text {pre }}\right)$. Hence, the distribution of expenditure on housing $p h$ is "shifted to the right" in region 2 with respect to region 1 . An uniform ceiling will affect the decisions of a larger share of the population in the high price region. 


\section{Figure 1}

\section{Evolution of Total Value of New Loans Under the Subsidy and General Regimes}

The figure presents the evolution of the total amount of new loans granted under the subsidized regime and the non-subsidized program over the 1990-2001 period. Data are collected from the Portuguese Finance Ministry.

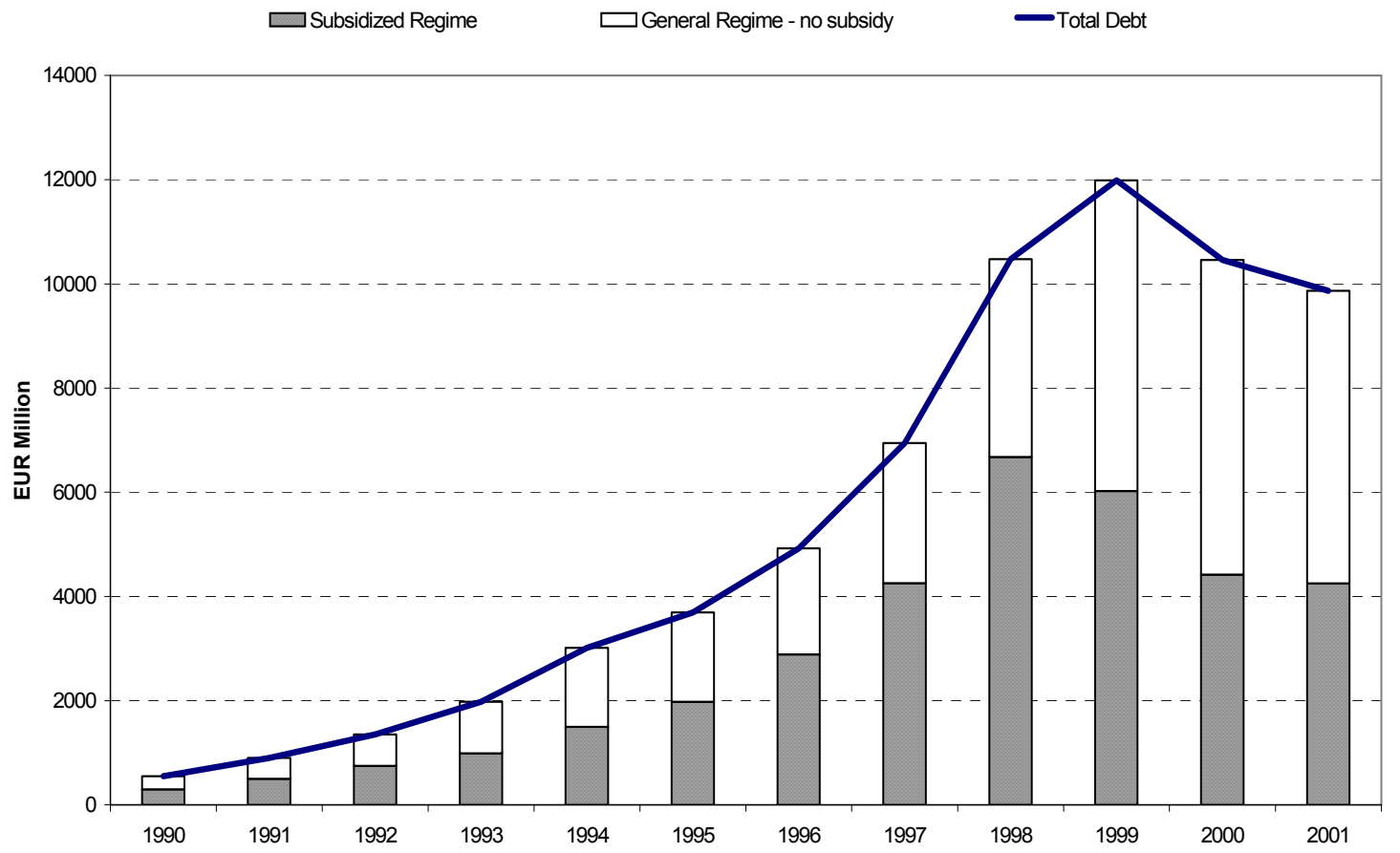




\section{Figure 2}

The figure present the effect of the 1999 reform of the CB program on the budget constraint of an individual eligible for the maximum subsidy The solid line represents the budget constraint of an eligible household before the 1998 reform. The dotted line represents the budget constraint of an eligible household after the 1998 reform.

Expenditure in non-durables

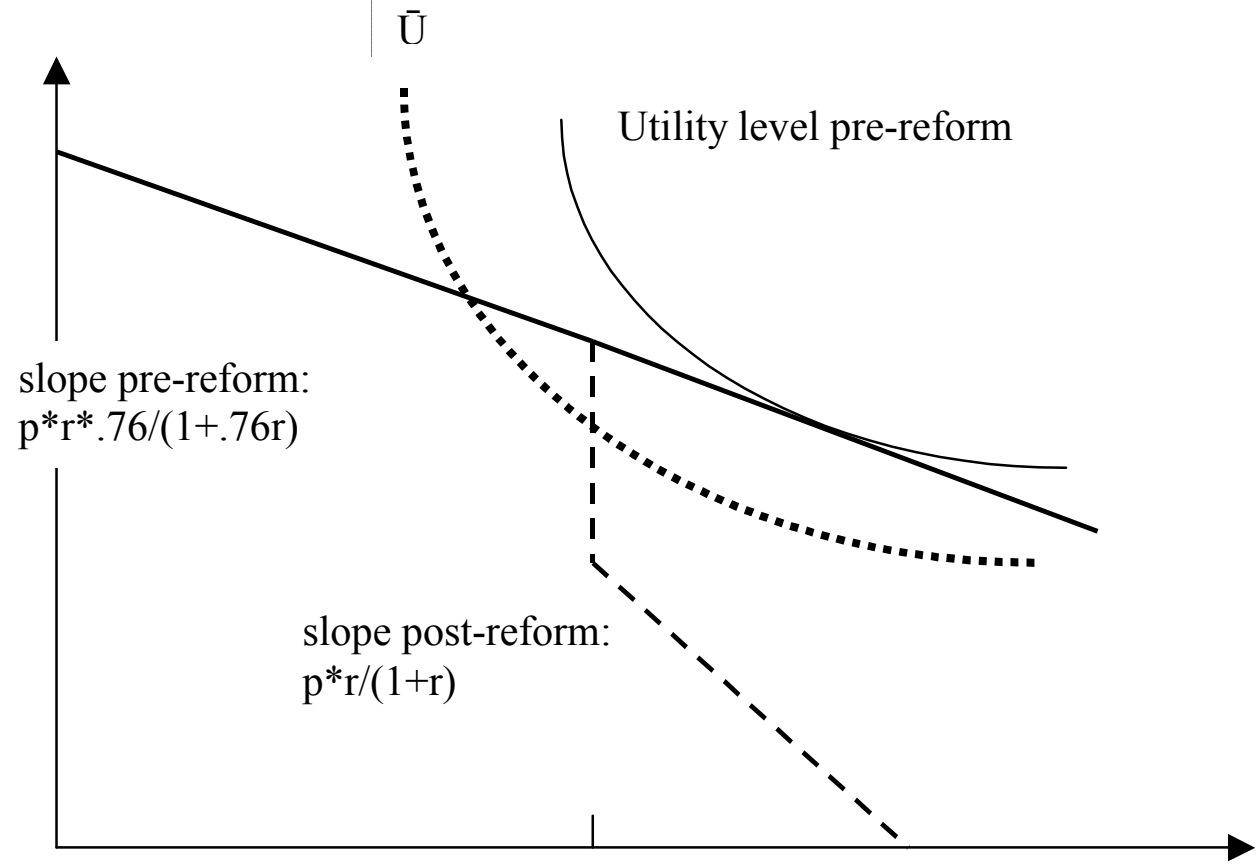

$\mathrm{L} / \mathrm{p}$
Housing services (h) 


\section{Figure 3}

Real Estate Price Index and Overall Interest Rate on Long-Term Loans

Source of the real estate price index: computed by the firm Confidencial Imobiliario Lda. The (monthly) index aggregates real estate prices for a set of real estate agencies. The value of the index in January 1989 is 100 . The interest rate is the aggregate level of interest rate on outstanding 5-year maturity loans or longer that were granted to households or emigrants, computed by the Banco de Portugal and published in the annual statistics bulletin.

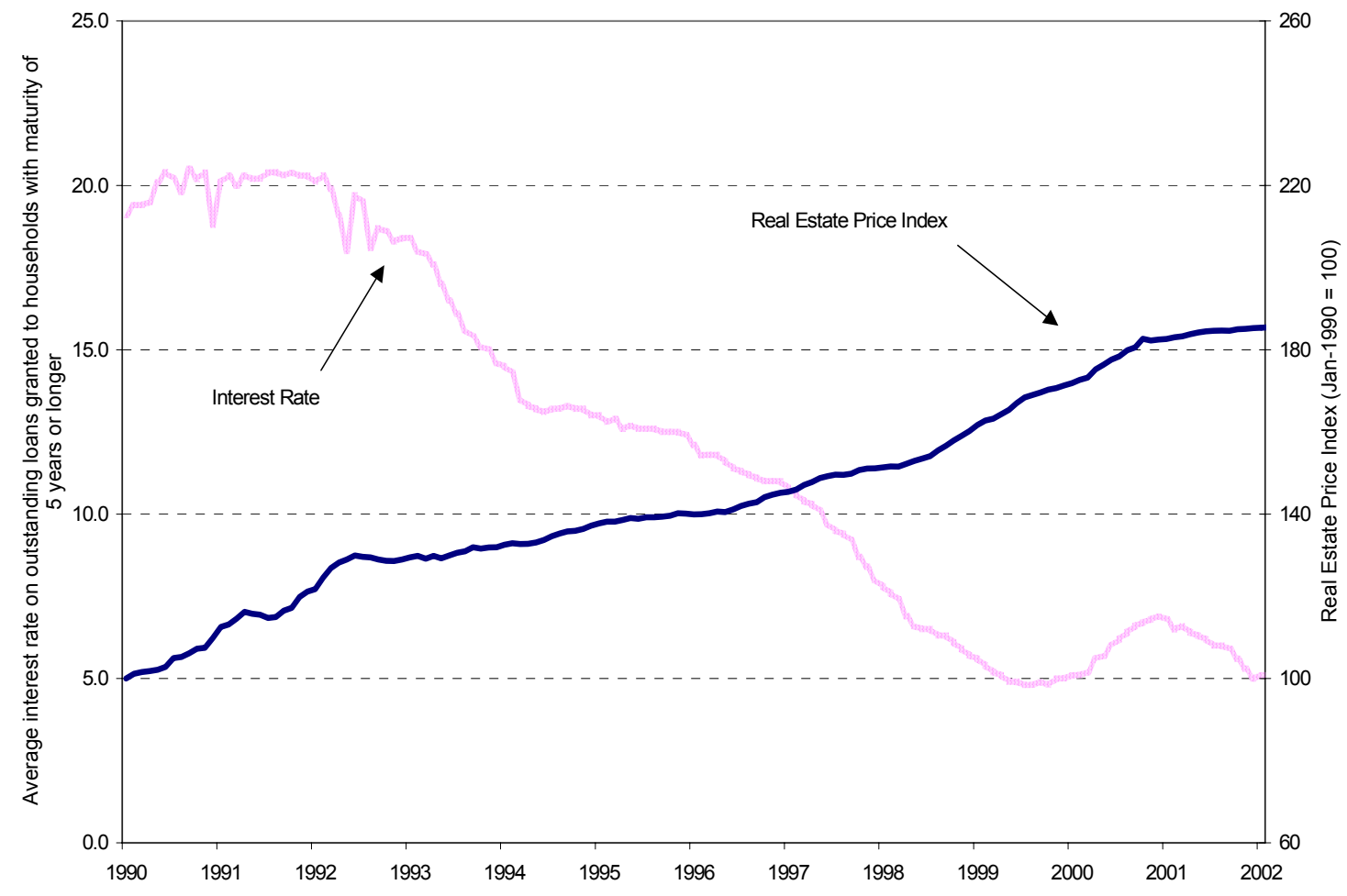


Table 1

\section{Savings Associated with the Credito Bonificado Program}

Columns (2) through (5) report simulated yearly payments of a 25-year mortgage without any subsidy. We asssume that there is no inflation and a constant interest rate of $8 \%$ throughout the 25 -year loan. The installment plan is determined for constant annual payments. Column (7) presents (non-discounted to period zero) payments of the same mortgage, for a person eligible for class I subsidy.

\begin{tabular}{|c|c|c|c|c|c|c|}
\hline $\begin{array}{c}\text { Age loan } \\
(1)\end{array}$ & $\begin{array}{c}\text { Debt } \\
(2)\end{array}$ & $\begin{array}{c}\text { Paymt } \\
(3)\end{array}$ & $\begin{array}{c}R^{-\left(a g e_{-} \operatorname{loan}\right)} \\
(4)\end{array}$ & $\begin{array}{l}\text { Disc. Paymt } \\
(5)=(4) *(3)\end{array}$ & $\begin{array}{l}\text { \% Subsidy } \\
(6)\end{array}$ & $\begin{array}{r}\text { Paymt. CB } \\
(7)=(3) \text {-subsidy }\end{array}$ \\
\hline 0 & 48000 & & & & & \\
\hline 1 & 47400 & 4440 & 0.926 & 4111 & 0.44 & 2751 \\
\hline 2 & 46751 & 4440 & 0.857 & 3807 & 0.44 & 2772 \\
\hline 3 & 46051 & 4440 & 0.794 & 3525 & 0.43 & 2832 \\
\hline 4 & 45295 & 4440 & 0.735 & 3264 & 0.42 & 2893 \\
\hline 5 & 44478 & 4440 & 0.681 & 3022 & 0.41 & 2955 \\
\hline 6 & 43596 & 4440 & 0.630 & 2798 & 0.39 & 3053 \\
\hline 7 & 42643 & 4440 & 0.583 & 2591 & 0.37 & 3150 \\
\hline 8 & 41614 & 4440 & 0.540 & 2399 & 0.35 & 3246 \\
\hline 9 & 40503 & 4440 & 0.500 & 2221 & 0.33 & 3342 \\
\hline 10 & 39303 & 4440 & 0.463 & 2057 & 0.31 & 3436 \\
\hline 11 & 38007 & 4440 & 0.429 & 1904 & 0.29 & 3529 \\
\hline 12 & 36607 & 4440 & 0.397 & 1763 & 0.27 & 3619 \\
\hline 13 & 35095 & 4440 & 0.368 & 1633 & 0.25 & 3708 \\
\hline 14 & 33463 & 4440 & 0.340 & 1512 & 0.23 & 3795 \\
\hline 15 & 31699 & 4440 & 0.315 & 1400 & 0.21 & 3878 \\
\hline 16 & 29795 & 4440 & 0.292 & 1296 & 0.19 & 3959 \\
\hline 17 & 27738 & 4440 & 0.270 & 1200 & 0.17 & 4035 \\
\hline 18 & 25517 & 4440 & 0.250 & 1111 & 0.15 & 4107 \\
\hline 19 & 23118 & 4440 & 0.232 & 1029 & 0.13 & 4175 \\
\hline 20 & 20527 & 4440 & 0.215 & 953 & 0.11 & 4237 \\
\hline 21 & 17729 & 4440 & 0.199 & 882 & 0.09 & 4293 \\
\hline 22 & 14707 & 4440 & 0.184 & 817 & 0.07 & 4341 \\
\hline 23 & 11443 & 4440 & 0.170 & 756 & 0.05 & 4382 \\
\hline 24 & 7918 & 4440 & 0.158 & 700 & 0.03 & 4413 \\
\hline 25 & 4111 & 4440 & 0.146 & 648 & 0.01 & 4434 \\
\hline 26 & 0 & 4440 & 0.135 & 600 & 0 & 4440 \\
\hline Disco & $\mathrm{P}$ & $t=\sum$ & $\begin{array}{l}=25 \quad \frac{\text { Paymt }}{R^{a g e}} \\
=0\end{array}$ & 48,000 & $\sum_{0}^{25} \frac{\text { PaymtCB }}{R^{a g e}}$ & 36,408 \\
\hline
\end{tabular}

Ratio [Class I] = Payment after subsidy 1 /Discounted Paymt $=36,408 / 48,000=0.76$

Ratio $[$ Class II] $=$ Payment after subsidy $2 /$ Discounted Paymt $\quad=40,203 / 48,000=0.84$

Ratio [Class III] $=$ Payment after subsidy $3 /$ Discounted Paymt $=44,117 / 48,000=0.92$

Ratio $[$ Class IV] $=$ Payment after subsidy 4 /Discounted Paymt $=46,366 / 48,000=0.97$ 


\section{Table 2}

\section{Descriptive Statistics of the Main Sample}

Income and debt are in 1999 euro. The sample is an unbalanced panel of 13,819 individuals. Each individual contributes with 1 observation in a given year, and at most 2 observations to the whole sample. Married households contribute one observation per year. Individuals with positive income co-residing with their parents contribute one observation per year. For individuals in their own household, family size excludes co-residing adults above 18 reporting positive income. The report of age, education or labor market situation corresponds to the main earner, unless otherwise stated. "Lived in a high price county" refers to the year prior to the interview. "New loan" refers to loans of maturity longer than one year.

\begin{tabular}{|c|c|c|c|c|c|c|c|c|c|c|}
\hline \multirow{4}{*}{$\begin{array}{l}\text { Number of observations: } \\
\text { Percentage in the whole sample }\end{array}$} & \multicolumn{2}{|c|}{ Class 1} & \multicolumn{2}{|c|}{ Class 2} & \multicolumn{2}{|c|}{ Classes III-IV } & \multicolumn{2}{|c|}{ "Non Eligible } & \multicolumn{2}{|c|}{ Whole Sample } \\
\hline & \multicolumn{2}{|c|}{11,238} & \multicolumn{2}{|c|}{1,294} & \multicolumn{2}{|c|}{1,371} & \multicolumn{2}{|c|}{2,684} & \multicolumn{2}{|c|}{16,587} \\
\hline & \multicolumn{2}{|c|}{$68.0 \%$} & \multicolumn{2}{|c|}{$7.8 \%$} & \multicolumn{2}{|c|}{$8.3 \%$} & \multicolumn{2}{|c|}{$16.1 \%$} & \multicolumn{2}{|c|}{$100.0 \%$} \\
\hline & Mean & StDev & Mean & StDev & Mean & StDev & Mean & StDev & Mean & StDev \\
\hline Signed new loan & 0.05 & 0.23 & 0.09 & 0.28 & 0.11 & 0.31 & 0.13 & 0.34 & 0.07 & 0.26 \\
\hline Amount of new loan, if positive & 29,225 & 28,423 & 27,166 & 27,482 & 28,402 & 27,656 & 32,920 & 32,071 & 29,976 & 29,359 \\
\hline Gross Yearly Income & 9,194 & 2,838 & 15,162 & 959 & 18,265 & 1,505 & 35,460 & 19,962 & 14,659 & 12,710 \\
\hline Family size & 2.21 & 1.37 & 2.19 & 1.23 & 2.23 & 1.23 & 2.48 & 1.31 & 2.26 & 1.35 \\
\hline Age & 34.01 & 11.18 & 35.07 & 10.29 & 35.48 & 9.91 & 38.85 & 9.48 & 35.01 & 10.90 \\
\hline Married & 0.47 & 0.50 & 0.53 & 0.50 & 0.55 & 0.50 & 0.61 & 0.49 & 0.51 & 0.50 \\
\hline Single & 0.45 & 0.50 & 0.41 & 0.49 & 0.39 & 0.49 & 0.31 & 0.46 & 0.42 & 0.49 \\
\hline Divorced & 0.05 & 0.23 & 0.05 & 0.21 & 0.05 & 0.22 & 0.07 & 0.25 & 0.06 & 0.23 \\
\hline Widow(er) & 0.02 & 0.14 & 0.05 & 0.21 & 0.01 & 0.10 & 0.01 & 0.10 & 0.02 & 0.14 \\
\hline Single female & 0.23 & 0.42 & 0.19 & 0.39 & 0.18 & 0.38 & 0.20 & 0.40 & 0.22 & 0.41 \\
\hline Co-resides with parents & 0.47 & 0.50 & 0.41 & 0.49 & 0.38 & 0.49 & 0.27 & 0.44 & 0.42 & 0.49 \\
\hline Illiterate & 0.04 & 0.20 & 0.02 & 0.14 & 0.01 & 0.09 & 0.00 & 0.04 & 0.03 & 0.18 \\
\hline Compl. 6th grade basic school & 0.63 & 0.48 & 0.49 & 0.50 & 0.41 & 0.49 & 0.16 & 0.36 & 0.52 & 0.50 \\
\hline Basic schooling-vocational training & 0.31 & 0.46 & 0.39 & 0.49 & 0.41 & 0.49 & 0.40 & 0.49 & 0.33 & 0.47 \\
\hline College degree & 0.02 & 0.04 & 0.10 & 0.30 & 0.17 & 0.38 & 0.44 & 0.50 & 0.11 & 0.31 \\
\hline Works for public Sector & 0.06 & 0.23 & 0.12 & 0.33 & 0.12 & 0.33 & 0.22 & 0.41 & 0.09 & 0.29 \\
\hline Part time & 0.02 & 0.15 & 0.02 & 0.12 & 0.01 & 0.10 & 0.02 & 0.14 & 0.02 & 0.14 \\
\hline Secondary earner self-employed & 0.04 & 0.20 & 0.03 & 0.17 & 0.03 & 0.18 & 0.03 & 0.18 & 0.04 & 0.20 \\
\hline Secondary earner does not work & 0.15 & 0.35 & 0.04 & 0.21 & 0.56 & 0.50 & 0.04 & 0.20 & 0.11 & 0.32 \\
\hline Lived in high price county & 0.49 & 0.49 & 0.52 & 0.50 & 0.46 & 0.50 & 0.62 & 0.49 & 0.52 & 0.50 \\
\hline Average price in county - 1998 & 82,078 & 11,163 & 83,564 & 12,838 & 8,578 & 13,535 & 123,703 & 14,328 & 83,282 & 12,221 \\
\hline
\end{tabular}




\section{Table 3}

\section{Differences-in-differences Results: Proportion of Borrowers and Average Debt Amount}

Means are unweighted. Coefficients and standard errors (in parentheses) for the proportion of borrowers are obtained from regressing the probability of signing a new loan on a post-reform dummy, eligibility dummies and interaction terms between the former variables. For the amount of debt regressions, the same covariates are used, and the dependent variable is the amount of the new loan (zeroes included.) Standard errors in all specifications are corrected for heteroskedasticity and autocorrelation between observations of the same individual. "Non-eligibles" refers to individuals who do not qualify for the program on the basis of their income.

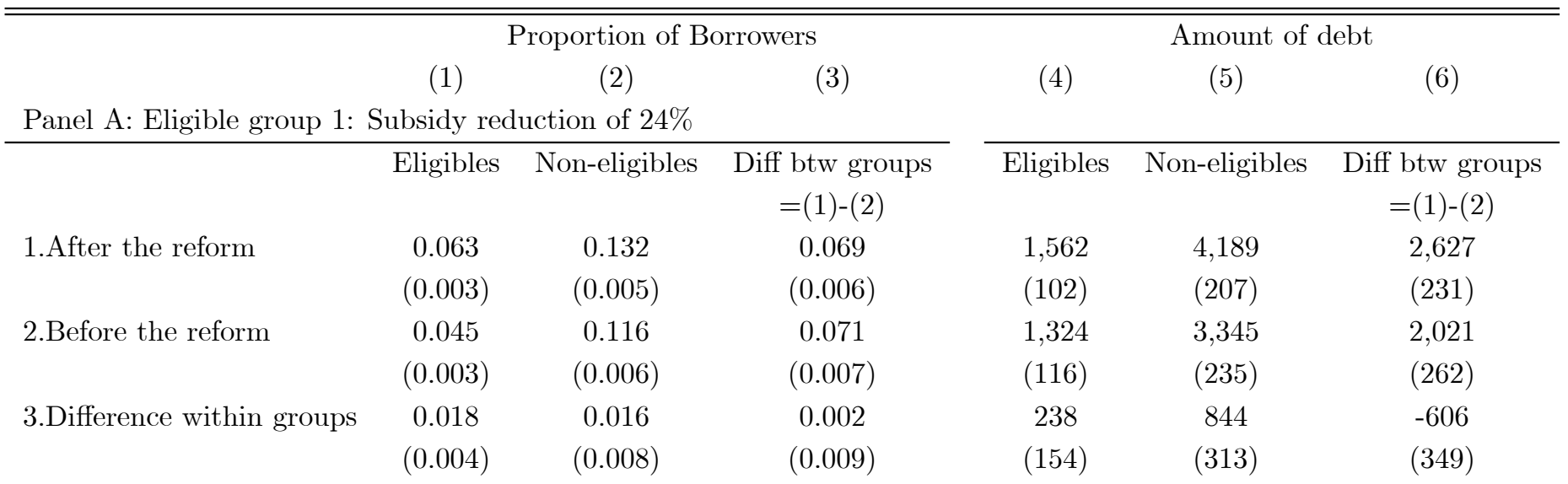

Panel B: Eligible group 2: Subsidy reduction of $16 \%$

\begin{tabular}{|c|c|c|c|c|c|c|}
\hline & Eligibles & Non-eligibles & $\begin{array}{c}\text { Diff btw groups } \\
=(1)-(2)\end{array}$ & Eligibles & Non-eligibles & $\begin{array}{c}\text { Diff btw groups } \\
=(1)-(2)\end{array}$ \\
\hline \multirow[t]{2}{*}{ 4.After the reform } & 0.097 & 0.132 & 0.035 & 2,352 & 4,189 & 1,837 \\
\hline & $(0.007)$ & $(0.005)$ & $(0.009)$ & $(300)$ & $(207)$ & $(365)$ \\
\hline \multirow[t]{2}{*}{ 5.Before the reform } & 0.079 & 0.116 & 0.037 & 2,590 & 3,345 & 755 \\
\hline & $(0.009)$ & $(0.006)$ & $(0.011)$ & $(367)$ & $(235)$ & $(435)$ \\
\hline \multirow[t]{2}{*}{ 6.Difference within groups } & 0.018 & 0.016 & 0.002 & -238 & 844 & $-1,082$ \\
\hline & $(0.012)$ & $(0.008)$ & $(0.014)$ & $(474)$ & $(313)$ & $(568)$ \\
\hline \multicolumn{7}{|c|}{ Panel C: Eligible Groups 3 and 4: subsidy reduction $8 \%$ and $4 \%$} \\
\hline & Eligibles & Non-eligibles & $\begin{array}{l}\text { Diff btw groups } \\
\quad=(1)-(2)\end{array}$ & Eligibles & Non-eligibles & $\begin{array}{c}\text { Diff btw groups } \\
=(1)-(2)\end{array}$ \\
\hline \multirow[t]{2}{*}{ 7.After the reform } & 0.110 & 0.132 & 0.022 & 3,261 & 4,189 & 928 \\
\hline & $(0.009)$ & $(0.005)$ & $(0.011)$ & $(289)$ & $(207)$ & $(356)$ \\
\hline \multirow[t]{2}{*}{ 8.Before the reform } & 0.088 & 0.116 & 0.028 & 2,038 & 3,345 & 1,307 \\
\hline & $(0.012)$ & $(0.006)$ & $(0.010)$ & $(351)$ & $(235)$ & $(422)$ \\
\hline \multirow[t]{2}{*}{ 9.Difference within groups } & 0.022 & 0.016 & -0.006 & 1,223 & 844 & -379 \\
\hline & $(0.013)$ & $(0.008)$ & $(0.015)$ & $(455)$ & $(313)$ & $(552)$ \\
\hline
\end{tabular}




\section{Table 4}

The Impact of the 1999 Reform on the Probability of Signing a New Loan - OLS Estimations

Coefficients are from OLS estimates of model (2). Standard errors, in parentheses, are corrected for heteroskedasticity and arbitrary correlation between observations from the same individual in specifications (1) and (2). In (3), standard errors allow for autocorrelation within the county. The omitted education group is "completed primary schooling or vocational training". The omitted marital status group is "married". The omitted employment status group is "employed individuals working in the private sector". The logarithm of per capita family income is the deviation from sample means. The symbols *, **, *** denote that the hypothesis of the coefficient being different from zero is rejected at the $10 \%, 5 \%$ and $1 \%$ significance level. The estimation method is Ordinary Least Squares.

Dependent variable takes value 1 if individual acquired long-term debt during the year, 0 otherwise.

(1)

(2)

(3)

[No covariates] [Limited Covariates] [County Fixed-eff.

\begin{tabular}{|c|c|c|c|c|c|c|}
\hline & Coeff. & St.Dev. & Coeff. & St.Dev. & Coeff. & St.Dev. \\
\hline ELIG1*AFTER*HIGHPRICE & -0.052 & $(0.029)^{*}$ & -0.054 & $(0.029)^{*}$ & -0.055 & $(0.032)^{*}$ \\
\hline ELIG2*AFTER*HIGHPRICE & -0.103 & $(0.042)^{* *}$ & -0.102 & $(0.042)^{* *}$ & -0.094 & $(0.041)^{* *}$ \\
\hline ELIG3*AFTER*HIGHPRICE & -0.043 & $(0.044)$ & -0.040 & $(0.044)$ & -0.039 & $(0.053)$ \\
\hline ELIG1*AFTER & 0.032 & $(0.023)$ & 0.033 & $(0.023)$ & 0.030 & $(0.021)$ \\
\hline ELIG2*AFTER & 0.054 & $(0.031)^{*}$ & 0.054 & $(0.031)^{*}$ & 0.045 & $(0.031)$ \\
\hline ELIG3*AFTER & 0.014 & $(0.035)$ & 0.013 & $(0.034)$ & 0.013 & $(0.042)$ \\
\hline ELIG1*HIGHPRICE & 0.031 & $(0.021)$ & 0.032 & $(0.021)$ & 0.032 & $(0.021)$ \\
\hline ELIG2*HIGHPRICE & 0.071 & $(0.031)^{* *}$ & 0.070 & $(0.031)^{* *}$ & 0.068 & $(0.029)^{* *}$ \\
\hline ELIG3*HIGHPRICE & 0.019 & $(0.033)$ & 0.018 & $(0.033)$ & 0.020 & $(0.035)$ \\
\hline ELIG1 & -0.095 & $(0.017)^{* * *}$ & -0.078 & $(0.017)^{* * *}$ & -0.054 & $(0.016)^{* * *}$ \\
\hline ELIG2 & -0.081 & $(0.023)^{* * *}$ & -0.072 & $(0.023) * * *$ & -0.058 & $(0.024)^{* *}$ \\
\hline ELIG3 & -0.030 & $(0.026)$ & -0.025 & $(0.026)$ & -0.018 & $(0.027)$ \\
\hline AFTER & -0.021 & $(0.022)$ & -0.019 & $(0.022)$ & -0.014 & $(0.019)$ \\
\hline AFTER*HIGHPRICE & 0.060 & $(0.028)^{* *}$ & 0.059 & $(0.028) * *$ & 0.056 & $(0.029)^{* *}$ \\
\hline HIGHPRICE & -0.040 & $(0.020)^{* *}$ & -0.040 & $(0.020)^{* *}$ & 0.000 & $(0.000)$ \\
\hline$($ Age -30$) / 10$ & & & 0.008 & $(0.005)^{*}$ & 0.005 & $(0.005)$ \\
\hline$($ Age -30$) *($ Age -30$) / 100$ & & & -0.022 & $(0.004)^{* * *}$ & -0.020 & $(0.004)^{* * *}$ \\
\hline$($ Age -30$)($ Age -30$)($ Age -30$) / 1000$ & & & 0.004 & $(0.002)^{* *}$ & 0.003 & $(0.002)^{*}$ \\
\hline Single female & & & -0.025 & $(0.005)^{* * *}$ & -0.018 & $(0.005)^{* * *}$ \\
\hline Number of adults - 2 & & & -0.007 & $(0.005)$ & -0.010 & $(0.006)^{*}$ \\
\hline Inverse of family size $-1 / 2$ & & & -0.072 & $(0.011)^{* * *}$ & -0.284 & $(0.080)^{* * *}$ \\
\hline Principal earner illiterate & & & -0.043 & $(0.009)^{* * *}$ & -0.036 & $(0.010)^{* * *}$ \\
\hline Principal earner completed 6 th grade & & & -0.019 & $(0.005)^{* * *}$ & -0.017 & $(0.007)^{* *}$ \\
\hline Principal earner completed college & & & -0.001 & $(0.010)$ & -0.007 & $(0.013)$ \\
\hline Log. of per capita family income & & & & & 0.030 & $(0.009)^{* * *}$ \\
\hline Dependent & & & & & -0.023 & $(0.008)^{* * *}$ \\
\hline Single & & & & & -0.031 & $(0.010)^{* * *}$ \\
\hline Divorced & & & & & -0.037 & $(0.013)^{* * *}$ \\
\hline Widow(er) & & & & & -0.050 & $(0.011)^{* * *}$ \\
\hline Principal earner works for public sector & & & & & 0.013 & $(0.009)$ \\
\hline Principal earner works part time & & & & & 0.002 & $(0.011)$ \\
\hline Secondary earner self-employed & & & & & 0.037 & $(0.013)^{* * *}$ \\
\hline Principal earner not employed & & & & & -0.011 & $(0.012)$ \\
\hline Secondary earner not employed & & & & & 0.004 & $(0.007)$ \\
\hline Constant & 0.147 & $(0.016)^{* * *}$ & 0.172 & $(0.018)^{* * *}$ & 0.180 & $(0.012)^{* * *}$ \\
\hline Sample size & \multicolumn{6}{|c|}{16,587} \\
\hline R-squared & \multicolumn{2}{|r|}{0.01} & \multicolumn{2}{|r|}{0.03} & \multicolumn{2}{|r|}{0.04} \\
\hline
\end{tabular}




\section{Table 4 (cont.)}

The Impact of the 1999 Reform on the Probability of Signing a New Loan - Probit Estimations

Coefficients are from Probit estimates of model (2), and report the marginal effect of changing the covariate on the probability of signing a new debt, holding the rest of the covariates at sample means. Standard errors, in parentheses, are corrected for heteroskedasticity and arbitrary correlation between observations from the same individual in specifications (1) and (2). In (3), standard errors allow for autocorrelation within the county. The omitted education group is "completed primary schooling or vocational training". The omitted marital status group is "married". The omitted employment status group is "employed individuals working in the private sector". The logarithm of per capita family income is the deviation from sample means. The symbols ${ }^{*},{ }^{*},{ }^{* *}$ denote that the hypothesis of the coefficient being different from zero is rejected at the $10 \%, 5 \%$ and $1 \%$ significance level. The estimation method is a probit.

Dependent variable takes value 1 if individual acquired long-term debt during the year, 0 otherwise

(4)

(5)

(6)

[No Covariates] [Limited Covariates] [County Fixed-Eff.]

\begin{tabular}{|c|c|c|c|c|c|c|}
\hline & Coeff. & St.Dev. & Coeff. & St.Dev. & Coeff. & St.Dev. \\
\hline ELIG1*AFTER*HIGHPRICE & -0.025 & $(0.017)$ & -0.024 & $(0.016)$ & -0.028 & $(0.016)^{*}$ \\
\hline ELIG2*AFTER*HIGHPRICE & -0.050 & $(0.014)^{* * *}$ & -0.047 & $(0.013)^{* * *}$ & -0.043 & $(0.012)^{* * *}$ \\
\hline ELIG3*AFTER*HIGHPRICE & -0.021 & $(0.023)$ & -0.020 & $(0.023)$ & -0.025 & $(0.023)$ \\
\hline ELIG1*AFTER & 0.027 & $(0.017)$ & 0.026 & $(0.016)^{*}$ & 0.026 & $(0.016)^{*}$ \\
\hline ELIG2*AFTER & 0.049 & $(0.036)$ & 0.047 & $(0.034)$ & 0.039 & $(0.035)$ \\
\hline ELIG3*AFTER & 0.005 & $(0.025)$ & 0.005 & $(0.023)$ & 0.009 & $(0.032)$ \\
\hline ELIG1*HIGHPRICE & 0.014 & $(0.016)$ & 0.015 & $(0.016)$ & 0.019 & $(0.016)$ \\
\hline ELIG2*HIGHPRICE & 0.060 & $(0.040)^{*}$ & 0.066 & $(0.038)^{*}$ & 0.063 & $(0.037)^{*}$ \\
\hline ELIG3*HIGHPRICE & 0.008 & $(0.026)$ & 0.009 & $(0.025)$ & 0.019 & $(0.016)$ \\
\hline ELIG1 & -0.091 & $(0.015)^{* * *}$ & -0.064 & $(0.014)^{* * *}$ & -0.030 & $(0.012)^{* *}$ \\
\hline ELIG2 & -0.045 & $(0.010)^{* * *}$ & -0.037 & $(0.011)^{* * *}$ & -0.025 & $(0.015)^{*}$ \\
\hline ELIG3 & -0.015 & $(0.015)$ & -0.010 & $(0.015)$ & -0.006 & $(0.016)$ \\
\hline AFTER & -0.013 & $(0.014)$ & -0.008 & $(0.013)$ & -0.007 & $(0.012)$ \\
\hline AFTER*HIGHPRICE & 0.040 & $(0.021)^{* *}$ & 0.038 & $(0.020)^{*}$ & 0.037 & $(0.021)^{*}$ \\
\hline HIGHPRICE & -0.025 & $(0.013)^{* *}$ & -0.023 & $(0.012)^{* *}$ & -0.07 & $(0.016)^{* * *}$ \\
\hline$($ Age -30$) / 10$ & & & 0.014 & $(0.005)^{* * *}$ & 0.010 & $(0.005)^{*}$ \\
\hline$($ Age -30$) *($ Age -30$) / 100$ & & & -0.029 & $(0.005)^{* * *}$ & -0.024 & $(0.005)^{* * *}$ \\
\hline$($ Age -30$)($ Age -30$)($ Age -30$) / 1000$ & & & 0.007 & $(0.002)^{* * *}$ & 0.005 & $(0.002)^{* * *}$ \\
\hline Single female & & & -0.027 & $(0.005)^{* * *}$ & -0.020 & $(0.006)^{* * *}$ \\
\hline Number of adults - 2 & & & -0.010 & $(0.005)^{* *}$ & -0.012 & $(0.005)^{* *}$ \\
\hline Inverse of family size $-1 / 2$ & & & -0.066 & $(0.010)^{* * *}$ & -0.435 & $(0.069)^{* * *}$ \\
\hline Principal earner illiterate & & & -0.039 & $(0.007)^{* * *}$ & -0.034 & $(0.008)^{* * *}$ \\
\hline Principal earner completed 6 th grade & & & -0.018 & $(0.005)^{* * *}$ & -0.017 & $(0.006)^{* * *}$ \\
\hline Principal earner completed college & & & 0.001 & $(0.007)$ & -0.006 & $(0.008)$ \\
\hline Log. of per capita family income & & & & & 0.045 & $(0.007)^{* * *}$ \\
\hline Co-reside with parents & & & & & -0.016 & $(0.007)^{* *}$ \\
\hline Single & & & & & -0.019 & $(0.009)^{* *}$ \\
\hline Divorced & & & & & -0.026 & $(0.009)^{* * *}$ \\
\hline Widow(er) & & & & & -0.040 & $(0.007)^{* * *}$ \\
\hline Principal earner works for public sector & & & & & 0.012 & $(0.007)^{*}$ \\
\hline Principal earner works part time & & & & & 0.008 & $(0.012)$ \\
\hline Secondary earner self-employed & & & & & 0.034 & $(0.012)^{* * *}$ \\
\hline Principal earner not employed & & & & & -0.010 & $(0.012)$ \\
\hline Secondary earner not employed & & & & & 0.007 & $(0.006)$ \\
\hline
\end{tabular}

Observations

16,587

16,169

R squared

.02

.05

.07 
Table 5

The Impact of the 1999 Reform on the Probability of Holding Debt - Additional Robustness Checks

Standard errors, in parentheses, are corrected for heteroskedasticity and arbitrary correlation between observations from the same individual. We use the same set of covariates as in Table 4 . The symbols ${ }^{*},{ }^{* *},{ }^{* * *}$ denote that the hypothesis of the coefficient being different from zero is rejected at the $10 \%, 5 \%$ and $1 \%$ significance level.

\begin{tabular}{|c|c|c|c|}
\hline \multicolumn{4}{|c|}{ Dependent variable takes value 1 if individual acquired long-term debt during the year, 0 otherwise. } \\
\hline \multirow[t]{2}{*}{ Estimation method: } & OLS & OLS & OLS \\
\hline & $\begin{array}{l}\text { All counties, imputing } \\
\text { real estate inflation }\end{array}$ & $\begin{array}{l}\text { Minimum loan is set } \\
\text { at } 7,500 \text { euro }\end{array}$ & $\begin{array}{l}\text { Eligibility measure excludes } \\
\text { children of age below } 2\end{array}$ \\
\hline \multirow[t]{2}{*}{ ELIG1*AFTER*HIGHPRICE } & -0.038 & -0.043 & -0.043 \\
\hline & $(0.023)^{*}$ & $(0.024)^{*}$ & $(0.026)^{*}$ \\
\hline \multirow[t]{2}{*}{ ELIG2*AFTER*HIGHPRICE } & -0.079 & -0.063 & -0.085 \\
\hline & $(0.035)^{* *}$ & $(0.037)^{*}$ & $(0.040)^{* *}$ \\
\hline \multirow[t]{2}{*}{ ELIG3*AFTER*HIGHPRICE } & -0.016 & -0.005 & -0.016 \\
\hline & $(0.026)$ & $(0.027)$ & $(0.029)$ \\
\hline \multirow[t]{2}{*}{ ELIG1*AFTER } & 0.017 & 0.013 & 0.024 \\
\hline & $(0.016)$ & $(0.018)$ & $(0.019)$ \\
\hline \multirow[t]{2}{*}{ ELIG2*AFTER } & 0.038 & 0.011 & 0.034 \\
\hline & $(0.025)$ & $(0.026)$ & $(0.028)$ \\
\hline \multirow[t]{2}{*}{ ELIG3*AFTER } & 0.000 & -0.02 & -0.014 \\
\hline & $(0.017)$ & $(0.019)$ & $(0.020)$ \\
\hline \multirow[t]{2}{*}{ ELIG1*HIGHPRICE } & 0.021 & 0.029 & 0.027 \\
\hline & $(0.017)$ & $(0.018)$ & $(0.020)$ \\
\hline \multirow[t]{2}{*}{ ELIG2*HIGHPRICE } & 0.049 & 0.056 & 0.060 \\
\hline & $(0.026)^{*}$ & $(0.028)^{* *}$ & $(0.030)^{* *}$ \\
\hline \multirow[t]{2}{*}{ ELIG3*HIGHPRICE } & 0.003 & -0.001 & 0.004 \\
\hline & $(0.024)$ & $(0.025)$ & $(0.028)$ \\
\hline \multirow[t]{2}{*}{ ELIG1 } & -0.034 & -0.036 & -0.045 \\
\hline & $(0.016)^{* *}$ & $(0.017)^{* *}$ & $(0.019)^{* *}$ \\
\hline \multirow[t]{2}{*}{ ELIG2 } & -0.032 & -0.033 & $-0.041^{*}$ \\
\hline & $(0.020)$ & $(0.021)$ & $(0.023)$ \\
\hline \multirow[t]{2}{*}{ ELIG3 } & -0.001 & 0.007 & 0.005 \\
\hline & $(0.017)$ & $(0.018)$ & $(0.020)$ \\
\hline \multirow[t]{2}{*}{ AFTER } & -0.002 & -0.003 & -0.01 \\
\hline & $(0.016)$ & $(0.017)$ & $(0.018)$ \\
\hline \multirow[t]{2}{*}{ AFTER*HIGHPRICE } & 0.042 & 0.046 & 0.046 \\
\hline & $(0.022)^{*}$ & $(0.023)^{* *}$ & $(0.024)^{*}$ \\
\hline \multirow[t]{2}{*}{ HIGHPRICE } & -0.026 & -0.032 & 0.000 \\
\hline & $(0.016)^{*}$ & $(0.017)^{*}$ & 0.000 \\
\hline Observations & 22,970 & & 16,587 \\
\hline
\end{tabular}




\section{Table 6}

The Impact of the 1999 Reform on the Probability of Holding Debt - Individuals Co-residing with Parents

Coefficients are from OLS estimates of model (2). Standard errors, in parentheses, are corrected for heteroskedasticity and arbitrary correlation between observations from the same individual in specifications (1) and (2). In (3), standard errors allow for autocorrelation within the county. Specifications (1), (2) and (3) include the covariates listed in Table 4 (not shown.)

\begin{tabular}{|c|c|c|c|}
\hline \multirow[t]{3}{*}{$\mathrm{D}$} & \multicolumn{3}{|c|}{ Estimation Method : OLS } \\
\hline & (1) & (2) & $(3)$ \\
\hline & [No Covariates] & [Full Covariates] & [County Fixed-Eff.] \\
\hline \multirow[t]{2}{*}{ ELIG1*AFTER*HIGHPRICE } & -0.106 & -0.109 & -0.110 \\
\hline & $(0.048)^{* *}$ & $(0.048)^{* *}$ & $(0.047)^{* *}$ \\
\hline \multirow[t]{2}{*}{ ELIG2*AFTER*HIGHPRICE } & -0.109 & -0.109 & -0.092 \\
\hline & $(0.062)^{*}$ & $(0.062)^{*}$ & $(0.059)$ \\
\hline \multirow[t]{2}{*}{ ELIG3*AFTER*HIGHPRICE } & -0.137 & -0.133 & -0.133 \\
\hline & $(0.066)^{* *}$ & $(0.066)^{* *}$ & $(0.061)^{* *}$ \\
\hline \multirow[t]{2}{*}{ ELIG1*AFTER } & 0.071 & 0.073 & 0.068 \\
\hline & $(0.037)^{*}$ & $(0.037)^{*}$ & $(0.029)^{* *}$ \\
\hline \multirow[t]{2}{*}{ ELIG2*AFTER } & 0.072 & 0.071 & 0.054 \\
\hline & $(0.048)$ & $(0.048)$ & $(0.036)$ \\
\hline \multirow[t]{2}{*}{ ELIG3*AFTER } & 0.121 & 0.113 & 0.113 \\
\hline & $(0.051)^{* *}$ & $(0.051)^{* *}$ & $(0.044)^{* *}$ \\
\hline \multirow[t]{2}{*}{ ELIG1*HIGHPRICE } & 0.069 & 0.075 & 0.071 \\
\hline & $(0.038)^{*}$ & $(0.038)^{* *}$ & $(0.033)^{* *}$ \\
\hline \multirow[t]{2}{*}{ ELIG2*HIGHPRICE } & 0.066 & 0.070 & 0.054 \\
\hline & $(0.048)$ & $(0.048)$ & $(0.046)$ \\
\hline \multirow[t]{2}{*}{ ELIG3*HIGHPRICE } & 0.070 & 0.070 & 0.066 \\
\hline & $(0.050)$ & $(0.050)$ & $(0.040)$ \\
\hline \multirow[t]{2}{*}{ ELIG1 } & -0.120 & -0.090 & -0.080 \\
\hline & $(0.032)^{* * *}$ & $(0.035)^{* *}$ & $(0.032)^{* *}$ \\
\hline \multirow[t]{2}{*}{ ELIG2 } & -0.095 & -0.084 & -0.064 \\
\hline & $(0.039)^{* *}$ & $(0.040)^{* *}$ & $(0.036)^{*}$ \\
\hline \multirow[t]{2}{*}{ ELIG3 } & -0.095 & -0.085 & -0.081 \\
\hline & $(0.040)^{* *}$ & $(0.040)^{* *}$ & $(0.032)^{* *}$ \\
\hline \multirow[t]{2}{*}{ AFTER } & -0.060 & -0.062 & -0.055 \\
\hline & $(0.037)$ & $(0.036)^{*}$ & $(0.027)^{* *}$ \\
\hline \multirow[t]{2}{*}{ AFTER*HIGHPRICE } & 0.100 & 0.099 & 0.098 \\
\hline & $(0.047)^{* *}$ & $(0.047)^{* *}$ & $(0.044)^{* *}$ \\
\hline \multirow[t]{2}{*}{ HIGHPRICE } & -0.071 & -0.072 & -0.065 \\
\hline & $(0.037)^{*}$ & $(0.038)^{*}$ & $(0.037)^{*}$ \\
\hline Observations & 7,136 & 7,137 & 7,138 \\
\hline
\end{tabular}




\section{Table 7}

The Impact of the 1999 Reform on the Logarithm of the Amount of New Debt

Standard errors, in parentheses, are not corrected for heteroskedasticity or arbitrary correlation between observations from the same individual. Covariates have the same interpretation as in Table 4. One, two and three asterisks denotes that the hypothesis of the coefficient being different from zero is rejected at the $10 \%, 5 \%$ and $1 \%$ significance level.

\begin{tabular}{|c|c|c|c|c|c|c|c|c|}
\hline & \multicolumn{2}{|r|}{$\begin{array}{c}(1) \\
{[\mathrm{OLS}]}\end{array}$} & \multicolumn{2}{|c|}{$\begin{array}{c}(2) \\
\text { [Max. Likel.] }\end{array}$} & \multicolumn{2}{|c|}{$\begin{array}{c}(3) \\
{[\mathrm{OLS}]}\end{array}$} & \multicolumn{2}{|c|}{$\begin{array}{c}(4) \\
\text { [Max. Lik.] }\end{array}$} \\
\hline & Coeff. & St.Dev. & Coeff. & St.Dev. & Coeff. & St.Dev. & Coeff. & St.Dev. \\
\hline ELIG1*AFTER & -0.30 & $(0.130)^{* *}$ & -0.322 & $(0.127)^{* *}$ & -0.353 & $(0.192)^{*}$ & -0.387 & $(0.194)^{* *}$ \\
\hline ELIG2*AFTER & -0.48 & $(0.20)^{* *}$ & -0.50 & $(0.205)^{* *}$ & -0.79 & $(0.309)^{* *}$ & -0.850 & $(0.321)^{* * *}$ \\
\hline ELIG3*AFTER & 0.15 & $(0.182)$ & 0.14 & $(0.19)$ & -0.348 & $(0.276)$ & -0.304 & $(0.277)$ \\
\hline ELIG1*AFTER*HIGHPRICE & & & & & 0.098 & $(0.266)$ & 0.068 & $(0.260)$ \\
\hline ELIG2*AFTER*HIGHPRICE & & & & & 0.51 & $(0.400)$ & 0.565 & $(0.436)$ \\
\hline ELIG3*AFTER*HIGHPRICE & & & & & 0.82 & $(0.366)^{* *}$ & 0.812 & $(0.375)^{* *}$ \\
\hline ELIG1 & 0.22 & $(0.13)$ & 0.260 & $(0.141)^{*}$ & 0.23 & $(0.164)$ & 0.231 & $(0.176)$ \\
\hline ELIG2 & 0.20 & $(0.17)$ & 0.221 & $(0.172)$ & 0.40 & $(0.248)^{*}$ & 0.524 & $(0.265)^{* *}$ \\
\hline ELIG3 & -0.17 & $(0.144)$ & -0.17 & $(0.152)$ & -0.10 & $(0.232)$ & -0.002 & $(0.210)$ \\
\hline AFTER & 0.10 & $(0.107)$ & 0.11 & $(0.102)$ & 0.220 & $(0.163)$ & 0.259 & $(0.158)$ \\
\hline AFTER*HIGHPRICE & & & & & 0.173 & $(0.197)$ & -0.192 & $(0.198)$ \\
\hline HIGHPRICEl & & & & & 0.008 & -0.161 & 0.021 & $(0.159)$ \\
\hline$($ Age - 30)/10 & 0.11 & $(0.008)$ & 0.08 & $(0.009)$ & 0.012 & $(0.008)$ & 0.008 & $(0.009)$ \\
\hline$($ Age -30$) *($ Age -30$) / 100$ & -0.03 & $(0.001)^{* * *}$ & -0.02 & $(0.001)^{* *}$ & -0.003 & $(0.001)^{* * *}$ & -0.002 & $(0.001)^{* *}$ \\
\hline$($ Age-30) $($ Age-30)(Age-30)/1000 & $4 \mathrm{e}-4$ & $(3 e-4)$ & $4 \mathrm{e}-4$ & $(3 \mathrm{e}-4)$ & 0.000 & $(0.000)$ & 0.000 & $(0.000)$ \\
\hline Single female & 0.14 & $(0.104)$ & 0.16 & $(0.11)$ & 0.131 & $(0.106)$ & 0.165 & $(0.113)$ \\
\hline Number of adults - 2 & -0.032 & $(0.072)$ & -0.01 & $(0.075)$ & -0.071 & $(0.076)$ & -0.020 & $(0.076)$ \\
\hline Inverse of family size & -1.52 & $(1.30)$ & -1.34 & $(1.63)$ & -1.789 & $(1.299)$ & -1.235 & $(1.582)$ \\
\hline Illiterate & 0.152 & $(0.246)$ & 0.22 & $(0.24)$ & 0.160 & $(0.252)$ & 0.223 & $(0.244)$ \\
\hline Completed 6 th grade & -0.141 & $(0.065)^{* *}$ & -0.128 & $(0.070)$ & -0.143 & $(0.066)^{* *}$ & -0.126 & $(0.073)^{*}$ \\
\hline College degree & -0.025 & $(0.093)$ & -0.04 & $(0.093)$ & -0.040 & $(0.095)$ & -0.050 & $(0.093)$ \\
\hline Log of per capita family income & 0.14 & $(0.134)$ & 0.12 & $(0.17)$ & 0.134 & $(0.135)$ & 0.112 & $(0.163)$ \\
\hline Single & 0.061 & $(0.171)$ & 0.10 & $(0.171)$ & 0.157 & $(0.190)$ & 0.105 & $(0.172)$ \\
\hline Divorced & 0.195 & $(0.167)$ & 0.24 & $(0.190)$ & 0.276 & $(0.176)$ & 0.243 & $(0.192)$ \\
\hline Widow(er) & -0.366 & $(0.295)$ & -0.27 & $(0.36)$ & -0.370 & $(0.295)$ & -0.303 & $(0.359)$ \\
\hline Principal earner works for pub sector & -0.171 & $(0.077)^{* *}$ & -0.19 & $(0.085)^{* *}$ & -0.174 & $(0.078)^{* *}$ & -0.181 & $(0.085)^{* *}$ \\
\hline Principal earner works part time & 0.185 & $(0.191)$ & 0.17 & $(0.202)$ & 0.178 & $(0.190)$ & 0.166 & $(0.200)$ \\
\hline Secondary earner self-employed & 0.049 & $(0.111)$ & 0.03 & $(0.121)$ & 0.085 & $(0.112)$ & 0.048 & $(0.125)$ \\
\hline Principal earner not employed & 0.006 & $(0.156)$ & 0.01 & $(0.167)$ & 0.010 & $(0.161)$ & 0.016 & $(0.166)$ \\
\hline Secondary earner not employed & 0.041 & $(0.088)$ & 0.021 & $(0.090)$ & 0.058 & $(0.088)$ & 0.040 & $(0.089)$ \\
\hline \multicolumn{9}{|l|}{ Constant } \\
\hline Observations & \multirow{2}{*}{\multicolumn{2}{|c|}{$\begin{array}{r}1,248 \\
097\end{array}$}} & \multicolumn{2}{|c|}{16,587} & \multicolumn{2}{|c|}{1,248} & \multicolumn{2}{|c|}{16,587} \\
\hline R-squared & & & & & & 1074 & & \\
\hline
\end{tabular}




\section{Table 8}

The Impact of a Fake 1998 Reform on the Probability of Holding Debt

The sample includes observations from the 1998 and 1999 surveys. The dependent variable takes value 1 if a new loan was signed during the previous wave (i.e., if a loan is signed in 1997 for the 1998 surveys, or if a loan is signed in 1998 for the 1999 surveys.) AFTER takes value 1 if the observation is taken in any 1999 survey. The computation of eligibility is described in the text. Standard errors, in parentheses, are corrected for heteroskedasticity and arbitrary correlation between observations from the same individual in specifications (1) and (2). In (3), standard errors allow for autocorrelation within the county. Specifications (1), (2) and (3) include the same covariates listed in Table 4.

\begin{tabular}{|c|c|c|c|c|c|c|}
\hline \multicolumn{7}{|c|}{ "Dependent variable takes value 1 if individual acquired long-term debt during the previous year, 0 otherwise } \\
\hline Estimation method: & $\begin{array}{c}\text { OLS } \\
(1) \\
{[\text { No Cov. }]}\end{array}$ & $\begin{array}{c}\text { OLS } \\
(2) \\
{[\mathrm{No} \mathrm{Cov} .]}\end{array}$ & $\begin{array}{c}\text { OLS } \\
(3) \\
\text { [Limited Cov.] }\end{array}$ & $\begin{array}{l}\text { Probit } \\
\quad(1) \\
{[\text { No Cov.] }}\end{array}$ & $\begin{array}{c}\text { Probit } \\
(2) \\
\text { [No Cov.] }\end{array}$ & $\begin{array}{c}\text { Probit } \\
(3) \\
\text { [Limited Cov. }\end{array}$ \\
\hline ELIG1*AFTER*HIGHPRICE & & $\begin{array}{l}-0.012 \\
(0.019)\end{array}$ & $\begin{array}{l}-0.012 \\
(0.019)\end{array}$ & & $\begin{array}{l}-0.011 \\
(0.010)\end{array}$ & $\begin{array}{l}-0.009 \\
(0.009)\end{array}$ \\
\hline ELIG2*AFTER*HIGHPRICE & & $\begin{array}{c}0.008 \\
(0.034)\end{array}$ & $\begin{array}{c}0.008 \\
(0.034)\end{array}$ & & $\begin{array}{c}0.004 \\
(0.026)\end{array}$ & $\begin{array}{c}0.007 \\
(0.026)\end{array}$ \\
\hline ELIG3*AFTER*HIGHPRICE & & $\begin{array}{c}0.034 \\
(0.035)\end{array}$ & $\begin{array}{c}0.034 \\
(0.035)\end{array}$ & & $\begin{array}{c}0.047 \\
(0.047)\end{array}$ & $\begin{array}{c}0.045 \\
(0.044)\end{array}$ \\
\hline ELIG1*AFTER & $\begin{array}{c}-0.01 \\
(0.008)\end{array}$ & $\begin{array}{c}0.015 \\
(0.016)\end{array}$ & $\begin{array}{c}0.014 \\
(0.016)\end{array}$ & $\begin{array}{c}0.001 \\
(0.006)\end{array}$ & $\begin{array}{c}0.020 \\
(0.012)\end{array}$ & $\begin{array}{c}0.017 \\
(0.011)\end{array}$ \\
\hline ELIG2*AFTER & $\begin{array}{l}-0.011 \\
(0.014)\end{array}$ & $\begin{array}{c}0.010 \\
(0.022)\end{array}$ & $\begin{array}{c}0.010 \\
(0.022)\end{array}$ & $\begin{array}{l}-0.005 \\
(0.009)\end{array}$ & $\begin{array}{c}0.010 \\
(0.020)\end{array}$ & $\begin{array}{c}0.006 \\
(0.018)\end{array}$ \\
\hline ELIG3*AFTER & $\begin{array}{c}0.01 \\
(0.015)\end{array}$ & $\begin{array}{c}0.002 \\
(0.030)\end{array}$ & $\begin{array}{c}0.002 \\
(0.030)\end{array}$ & $\begin{array}{c}0.008 \\
(0.010)\end{array}$ & $\begin{array}{l}-0.005 \\
(0.018)\end{array}$ & $\begin{array}{l}-0.005 \\
(0.016)\end{array}$ \\
\hline ELIG1*HIGHPRICE & & $\begin{array}{l}-0.000 \\
(0.015)\end{array}$ & $\begin{array}{l}-0.001 \\
(0.015)\end{array}$ & & $\begin{array}{c}0.003 \\
(0.011)\end{array}$ & $\begin{array}{c}0.001 \\
(0.010)\end{array}$ \\
\hline ELIG2*HIGHPRICE & & $\begin{array}{c}0.008 \\
(0.020)\end{array}$ & $\begin{array}{c}0.006 \\
(0.020)\end{array}$ & & $\begin{array}{c}0.009 \\
(0.018)\end{array}$ & $\begin{array}{c}0.007 \\
(0.016)\end{array}$ \\
\hline ELIG3*HIGHPRICE & & $\begin{array}{l}-0.032 \\
(0.022)\end{array}$ & $\begin{array}{l}-0.032 \\
(0.022)\end{array}$ & & $\begin{array}{c}-0.025 \\
(0.008)^{* * *}\end{array}$ & $\begin{array}{c}-0.023 \\
(0.007)^{* * *}\end{array}$ \\
\hline ELIG1 & $\begin{array}{c}-0.052 \\
(0.006)^{* * *}\end{array}$ & $\begin{array}{c}-0.051 \\
(0.011)^{* * *}\end{array}$ & $\begin{array}{c}-0.044 \\
(0.011)^{* * *}\end{array}$ & $\begin{array}{c}-0.055 \\
(0.006)^{* * *}\end{array}$ & $\begin{array}{c}-0.055 \\
(0.011)^{* * *}\end{array}$ & $\begin{array}{c}-0.040 \\
(0.010)^{* * *}\end{array}$ \\
\hline ELIG2 & $\begin{array}{c}-0.024 \\
(0.010)^{* *}\end{array}$ & $\begin{array}{c}-0.036 \\
(0.015)^{* *}\end{array}$ & $\begin{array}{c}-0.033 \\
(0.016)^{* *}\end{array}$ & $\begin{array}{c}-0.014 \\
(0.005)^{* * *}\end{array}$ & $\begin{array}{c}-0.021 \\
(0.007)^{* * *}\end{array}$ & $\begin{array}{c}-0.016 \\
(0.008)^{* *}\end{array}$ \\
\hline ELIG3 & $\begin{array}{c}-0.026 \\
(0.008)^{* * *}\end{array}$ & $\begin{array}{l}-0.003 \\
(0.018)\end{array}$ & $\begin{array}{l}-0.003 \\
(0.018)\end{array}$ & $\begin{array}{c}-0.014 \\
(0.004)^{* * *}\end{array}$ & $\begin{array}{c}0.009 \\
(0.015)\end{array}$ & $\begin{array}{c}0.010 \\
(0.014)\end{array}$ \\
\hline AFTER & $\begin{array}{c}0.019 \\
(0.008)^{* *}\end{array}$ & $\begin{array}{l}-0.001 \\
(0.016)\end{array}$ & $\begin{array}{l}-0.001 \\
(0.015)\end{array}$ & $\begin{array}{c}0.011 \\
(0.004)^{\text {** }}\end{array}$ & $\begin{array}{l}-0.001 \\
(0.009)\end{array}$ & $\begin{array}{c}0.000 \\
(0.008)\end{array}$ \\
\hline AFTER*HIGHPRICE & & $\begin{array}{c}0.005 \\
(0.018)\end{array}$ & $\begin{array}{c}0.005 \\
(0.018)\end{array}$ & & $\begin{array}{c}0.003 \\
(0.011)\end{array}$ & $\begin{array}{c}0.001 \\
(0.010)\end{array}$ \\
\hline HIGHPRICE & & $\begin{array}{c}0.003 \\
(0.014)\end{array}$ & $\begin{array}{c}0.005 \\
(0.014)\end{array}$ & & $\begin{array}{c}0.002 \\
(0.008)\end{array}$ & $\begin{array}{c}0.003 \\
(0.007)\end{array}$ \\
\hline Constant & $\begin{array}{c}0.077 \\
(0.006)^{* * *}\end{array}$ & $\begin{array}{c}0.071 \\
(0.010)^{* * *}\end{array}$ & $\begin{array}{c}0.090 \\
(0.011)^{* * *}\end{array}$ & & & \\
\hline Observations & 13,886 & 15,503 & 15,503 & 13,886 & 15,503 & 15,503 \\
\hline R-squared & 0.03 & 0.01 & 0.02 & & & \\
\hline
\end{tabular}

